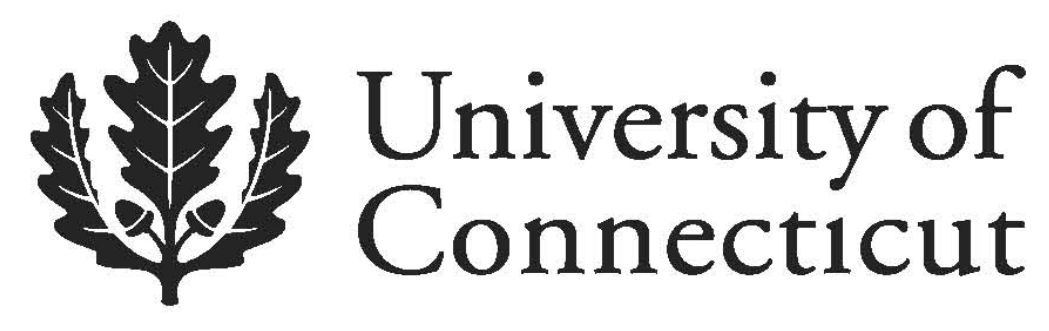

Department of Economics Working Paper Series

Improving the Labor Market Outcomes of Minorities: The Role of Employment Quota

Nishith Prakash

University of Connecticut, CReAM, \& IZA

Working Paper 2012-32

December 2010

365 Fairfield Way, Unit 1063

Storrs, CT 06269-1063

Phone: (860) 486-3022

Fax: (860) 486-4463

http://www.econ.uconn.edu/

This working paper is indexed on RePEc, http://repec.org 


\title{
Improving the Labor Market Outcomes of Minorities: The Role of Employment Quota
}

\author{
Nishith Prakash \\ University of Connecticut, IZA \& CReAM ${ }^{1}$
}

Draft: December 2010

\begin{abstract}
The world's biggest and arguably most aggressive form of employment based affirmative action policy for minorities exists in India. This paper exploits the institutional features of federally mandated employment quota policy to examine its effect on labor market outcomes of two distinct minority groups. My main finding is that employment quota significantly increases the probability of acquiring a salaried job for one minority group and not the other. Their improved employment outcome is also reflected in their higher household consumption expenditure. Overall, the effects vary within each minority group by education, gender, and geographical location.
\end{abstract}

JEL classification: H40, J21, J31, J45, O10.

Keywords: Caste, Employment, Wage differentials, Public Sector, India.

\footnotetext{
${ }^{1}$ Department of Economics and Human Rights Institute, University of Connecticut, Storrs, CT 06269 (e-mail: nishith.prakash@uconn.edu).

I thank Joshua Angrist, Mehtabul Azam, Chris Barrett, Marianne Bertrand, Aimee Chin, Steve Craig, Esther Duflo, Eric Edmonds, Shahe Emran, Larry Howard, Chinhui Juhn, Melanie Khamis, Anil Kumar, Rohini Pande, Tauhidur Rahman, Gergely Ujhelyi and participants at the Spring 2007 University of Houston Department of Economics Graduate Workshop, Federal Reserve Bank of Dallas, University of New South Wales, Ohio University, New York University, Delhi School of Economics, University of Gottingen, University of Aberdeen, Cornell University, NEUDC 2008, 8th Annual Missouri Economics Conference, International Conference on Development, Freedom and Welfare, IZA for helpful comments and discussion. Also, I thank officials at the Government of India Ministry of Social Justice and Empowerment, and Scheduled Caste and Scheduled Tribe Commissioner's office in New Delhi, India for data provision and discussion. Financial support from the University of Houston Department of Economics to collect data in India in Summer 2006 is gratefully acknowledged. Please do not cite without author's prior permission. I am responsible for any errors that may remain.
} 


\section{Introduction}

Affirmative action refers to policies used by government and other institutions to help historically disadvantaged groups. These policies have been proposed and used in many countries with the intention of compensating for the damages caused by the past discrimination. The nature and implementation of affirmative action policies differ across countries. These policies can be broadly classified into two categories. First is the policy of mandated quota system in which a certain number or share of jobs/seats are set aside for disadvantaged minorities in public sector enterprise, private sector enterprise, political spheres and educational institutions. This is used in India, Malaysia and Sri Lanka among other countries. Second is the policy of preferential treatment in which members of historically disadvantaged groups receive more favorable consideration for school admission or employment although no specific slots in the institution are actually set aside for them. Two examples of countries following the latter policy are USA and Great Britain. Both these models of affirmative action have an altruistic motive of uplifting the historically disadvantaged groups. It is an empirical question whether they really help the intended beneficiaries.

This paper estimates the effect of reserving jobs for historically disadvantaged groups on their labor market outcomes. In general, this is difficult to do because whether or how many jobs are set aside for minorities is likely to be endogenous. For example, institutions or places that reserve more jobs for minorities are likely more favorable to minorities in other ways too, which confounds the interpretation of the estimated coefficient for jobs reserved from a regression of some labor market outcome on jobs reserved. However, in India, the mandated employment quota is implemented in a way that facilitates the identification of the causal effect of reserving jobs. In particular, the Indian Constitution stipulates that in each state the share of public sector jobs reserved for scheduled castes

and scheduled tribes - the two principal historically disadvantaged groups in India- be equal to their share of the total population in the most recently tabulated census of population. This policy rule generates plausibly exogenous variation in share of jobs reserved, permitting the identification of the causal effect of job reservation on labor market outcomes. The variation I use is not based on all fluctuations in minority population share; this would be erroneous because we would expect minority population share to affect labor market outcomes not only through share of jobs reserved. Instead, the identification 
strategy takes advantage of the fact that the share of jobs set aside for minorities can only change with a lag with respect to both the current population share and the population share in the most recent census. There are two sources of the lag: (1) the current population varies continuously but job reservations are based on the census, which is taken only decennially; and (2) there is an administrative lag between when the census is taken and when the job reservations are adjusted to reflect the new census data. These jumps and administrative lags generated by the policy rule allow me to separately identify the effect of job reservation for minorities from the effect of contemporaneous changes in their population. ${ }^{1}$

I implement the identification strategy using individual-level data from multiple rounds of the National Sample Survey (NSS). First, I examine the effect of reserving jobs on the employment status of the people in targeted groups. Public sector employment is on average better than alternative employment opportunities for minorities-it provides a higher salary and better job security-thus it is possible that job reservations change incentives to work or the composition of employment conditional on working (e.g., away from self-employment or casual work, toward a salaried job). Second, I examine the effect of reserving jobs on the wages and expenditures of the people in targeted groups. Third, I examine whether effects vary by sex, sector (rural/urban) and educational attainment. My primary finding is that reserving jobs does not significantly change the probability of working or working in paid employment for either scheduled castes or scheduled tribes, but does raise the probability that a scheduled caste member works in a salaried job. The effects are similar for both men and women, and benefits are more pronounced in urban areas and for the less educated. Another finding is that reserving jobs does not increase wages or per capita household expenditure on average, but less educated scheduled caste members do experience significant increases in their expenditure, probably due to their greater propensity to have a salaried job. Overall then, job reservations for scheduled tribes do not significantly improve scheduled tribe members' labor market outcomes (at least those outcomes available in the NSS data) while job reservations for scheduled castes do enable some scheduled caste members to get better jobs.

An evaluation of the job reservation policy in India should be of interest for a number of reasons. First, I am not aware of previous studies that rigorously quantify the effects of this policy. Yet this is the largest mandated employment quota policy in the world, and

\footnotetext{
${ }^{1} \mathrm{~A}$ diagrammatic representation of the identification is in Figure 1
} 
has existed for over a half century. Second, this paper adds to the existing literature on the effects of affirmative action. Affirmative action policies are the subject of heated debates in many countries, and it is important to understand whether they benefit the intended beneficiaries in the first place before adopting or continuing them. Some affirmative action policies may have different effects than others, and this case of setting aside jobs for minorities in India should be an interesting counterpoint for policies based on preferential treatment without mandates.

The remainder of this paper proceeds as follows: Section 2 briefly discusses the related literature. Section 3 provides a background on disadvantaged minorities and the job reservation policy in India. Section 4 describes the data. Section 5 presents the empirical framework. Section 6 reports the main empirical results, and Section 7 describes some robustness checks. Section 8 concludes.

\section{Related Literature}

There is an extensive literature on affirmative action, and this paper contributes to the strand estimating the effects of employment-related affirmative action policies on the outcomes of targeted groups. Most of these studies have examined the United States experience (e.g., Freeman 1973, Ashenfelter and Heckman 1976, Brown 1984, Leonard 1990, Donohue and Heckman 1991). One set of studies has focused on the federal contractor program. Under this program, targeted groups (including blacks and women) are given preferential treatment when bidding for business from the federal government (e.g., Leonard 1984b). Leonard (1984b) finds that affirmative action has not only increased minority employment among contractors, it has also increased the demand for minorities in skilled jobs in the contractor sector. The literature's consensus is that federal contractor program has had somewhat modest effects on black economic outcomes (Smith and Welch 1989, Leonard 1990).

A second set of studies estimating the effect of employment-related affirmative action policies has focused court-ordered affirmative action (e.g., Beller 1978), but as noted by Donohue and Heckman (1991), no consensus has emerged on the evidence, and the interpretation is difficult due to endogeneity problems. Leonard (1984a) estimates small productivity impacts of court-ordered affirmative action using industry-level data on class action employment discrimination litigation, black employment, and productivity. More 
recently, McCrary (2007) estimates the effect of court-ordered racial hiring quotas on municipal police departments in Unites States. He finds a 14 percentage point gain in the fraction African American among newly hired officers.

To my knowledge this paper is the first to quantify the effects the job reservation policy in India on the labor market outcomes of targeted groups, and as such makes a contribution to the literature on the effects of employment-related affirmative action policies. (A good qualitative discussion of the job reservation policy in India is offered by Galanter (1984).) However, a number of recent papers have examined the effects of political reservation policy in India. In India, a certain number of seats in federal, state and local legislative bodies are set aside for minorities and women. Pande (2003) finds that changing the political representation for scheduled tribes and scheduled castes does impact policy choices, which is consistent with policy preferences differing across social groups and politicians acting upon their preferences. Duflo and Chattopadhyay (2004) finds that increasing female political representation changes the policy choices as well; local governments where a woman is randomly assigned to be a leader tend to invest more in public goods that women consider more important. Prakash (2007) finds that political reservation for minorities has reduced overall poverty in India. Thus, mandated political quotas appear to have a beneficial effect for the group for whom slots are set aside. It is of interest to find out whether mandated employment quotas, too, benefit their intended beneficiaries.

\section{Background}

\subsection{The Scheduled Castes and Scheduled Tribes in India}

The scheduled castes (SCs) and scheduled tribes (STs) are the two principal historically disadvantaged minority groups in India, and together account for 24.4 percent of the total population according to 2001 census. Table 1 provides the legal definition of these two social groups. The SCs, who make up 16.4 percent of the total population, is comprised of groups isolated and disadvantaged by their "untouchability" 2 status. The word "untouchability" refers to their low status in the traditional Hindu caste hierarchy which exposed them to invidious treatment, severe disabilities, and deprivation of eco-

\footnotetext{
${ }^{2}$ The Indian Constitution prohibits the use of the word untouchability.
} 
nomic, social, cultural, and political opportunities (Galanter 1984). The STs, who make up 7.9 percent of the total population, are distinguished by "tribal characteristics" and by their spatial and cultural isolation from rest of the population. In addition to the aforementioned characteristics, the identity of SCs and STs is historically determined. An individual is born as SC or ST and cannot change his/her caste over the lifetime. The only way to assimilate is through inter-caste marriage, in which case the children will acquire the father's caste identity. In practice, inter-caste marriage is extremely rare for both STs and SCs. Economic and social advancement of any group in a society requires an inclusive development, but the SCs and STs in India were excluded from every possible ritual practices and institutional rights, hence leaving them far behind the non-minorities.

The discrimination against SCs and STs over the past 1500 years is reflected today in their much worse socioeconomic status relative to the non-minorities. The poverty rate (percentage of people below Indian poverty line, measured by headcount ratio) among the disadvantaged minorities is about twice as high as for the rest of the population (see Table 2). Table 2 shows that the SCs and STs are worse off by other measures of well-being as well: infant mortality rate, literacy rate, and school enrollment rate. This systematic deprivation across all spheres has further led to their low educational achievements. According to the National Sample Survey (NSS) in 2005, only 52.4 percent of ST and 58.2 percent of SC children (age 6-14) can read and write as compared to 72.0 percent of non-minorities.

The large disparities in well-being between these two historically disadvantaged minority groups and the non-minorities has been the impetus for many government policies aimed at helping the SCs and STs. Among these policies is the job reservation policy.

\subsection{The Job Reservation Policy in India}

"Nothing in this article shall prevent the State from making any provision for the reservation of appointments or posts in favor of any backward class of citizens which in the opinion of the State, is not adequately represented in the services under the State."

Article 16(4), Constitution of India. 
The history of reservation policy for disadvantaged minorities in public sector jobs dates back to 1947, when India attained Independence. Specifically, Articles 16(4), 320(4) and 335 of the Indian Constitution provides safeguards for SCs and STs in services and posts under the state with a view to ensuring their adequate representation in the public sector jobs. The percentage of reservation in services/posts under the state government varies from one state to another and is fixed on the basis of percentage of SC and ST population in the respective state ${ }^{3}$. This policy of official discrimination in favor of the worst off sections of the population is unique in the world, both in the range of benefits involved and in magnitude of the groups eligible for the benefits.

The job reservation policy in India is handled by the National Scheduled Caste and Scheduled Tribe Commission. This Commission co-ordinates between the state government and the federal government once the fresh census population estimates by social group arrive. Before implementing the recommendation by the Commission, approval from several bodies is required. After the fresh estimates arrive, the Commission revises the percent of jobs reserved for SCs and STs according to the new census population estimates. Next, the Commission sends the recommendation to the President of India. Then the Ministry of Social Justice and Empowerment places the recommendation before both houses of the Parliament which gives the final approval. Only after this set of administrative steps is the percent of jobs reserved revised to reflect the new census population estimates. The details of how the job reservation policy is implemented in India will enable me to identify the effects of this policy, as I discuss in the next section.

Two additional comments are worth making about the job reservation policy in India. First, it is implemented on a flow basis. That is, the percent jobs reserved is applied to new vacancies. For example, if in a particular state 15 percent of jobs are reserved for SCs, then 15 percent of new vacancies will be set aside for SCs; only members of SCs would be eligible for these reserved jobs, though these reserved jobs may go unfilled in the absence of qualified candidates. Continuing the example, no non-minorities holding public sector jobs are removed from their jobs and replaced with members of SCs to make it true that 15 percent of the stock of public sector jobs are occupied by SCs. Second, it provides mandated employment quotas wherein the quotas are not upper limits on extent of minority employment in the public sector; indeed, minorities are free to compete for unreserved jobs, which are open to all.

\footnotetext{
${ }^{3}$ Annual Scheduled Caste and Scheduled Tribe Commissioners Report.
} 


\section{Data and Descriptive Statistics}

The empirical analysis uses data assembled from a variety of sources. This section gives a brief summary of the data sources and the variables used; Appendix A provides a detailed account of the same.

The primary source is the National Sample Survey (NSS). This provides a large, nationally representative sample of households in India. I use data from the Employment and Unemployment rounds of this survey in 1983, 1987, 1993, and 1999. From the NSS, I extract the following sample: individuals who are currently aged 18-40, living in one of the 16 major Indian states named in Appendix A, and not currently attending school. The first data restriction is because only SCs and STs in this age range are eligible to apply for the reserved public sector jobs. The second restriction is because the job reservation variables that I cover in these states over the 1983-1999 time period consistently; at any rate, it should have minimal impact since these 16 states account for over 95 percent of the Indian population. All the labor market outcomes and individual demographic variables used in the empirical paper come from the NSS.

The Scheduled Caste and Scheduled Tribe Annual Commissioner's Report provides the policy variables for each state and year: percent of public sector jobs reserved for SCs and percent of public sector jobs reserved for STs. These policy variables are merged into the NSS individual-level data set by state and year.

The remaining data sources are as follows. The Census of India, Registrar General provides the data on SC and ST census population shares and current population shares. The Census Atlas, India provides population density data. Finally, state per capita income is from the Economic and Political Weekly Research Foundation. These data are at the state-year level, and merged into the NSS data set by state and year.

Table 3 reports the descriptive statistics by social group (STs, SCs and non-minorities) for the full sample. (Appendix B provides descriptive statistics by sector and gender.) My three main outcome variables are based on the NSS question regarding usual activity: probability of being employed, probability of being in paid employment ${ }^{4}$, and probability of being a salaried worker conditional on being in paid employment. These employment status outcomes are denoted as $\operatorname{Pr}$ (Employed), $\operatorname{Pr}$ (Paid Employed) and Pr(Salaried|Paid Employed), respectively. These three employment outcomes are dichotomous variables. ${ }^{5}$

\footnotetext{
${ }^{4}$ Paid employment is comprised of salaried, self-employed, and casual workers.
}

${ }^{5}$ Below I will be estimating models using OLS, i.e., using the linear probability model. It is known that in the linear 
In the sample, 77 percent of STs and 66 percent of SCs reports are employed, compared to 60 percent for non-minorities. About 60 percent of STs and SCs work in paid employment, compared to 48 percent for non-minorities. The lower employment and paid employment participation for non-minorities is not an indication of their worse opportunities. Instead, it is due to the better socioeconomic conditions for non-minorities that the women can work less and young men can study for civil service exams or engage in lengthy searches for well-matched job. Conditional on being in paid employment though, non-minorities have a larger likelihood of being in a salaried job.

An outcome of great interest would have been the probability of working in public sector employment, unfortunately this variable is available only in the 1999 round of the NSS and not in earlier ones. Still, I argue that it is possible to learn something about whether individuals are getting better jobs by looking at the three aforementioned employment outcomes. In particular, the different categories of employment status may be ranked as (from worse to better): not working, working, working for pay, and working in a salaried job. Public sector jobs belong to the latter category, and are among the better jobs in that category. This ranking is based on Table 4, which displays the mean monthly wages and MPCE for each employment category for men in the urban sector in the 1999 NSS. Wages are asked only of salaried and casual workers, and it is clear that salaried workers earn considerably more than casual workers, especially those in public sector employment. An individual's household's MPCE is available for all the different employment categories, so can be used for a more complete comparison. Average monthly per capita expenditure is again highest for salaried workers. Hence, amongst the different employment categories, salaried jobs can be considered "good jobs" in a loose sense in the Indian context.

Despite the shortcomings of the NSS data-e.g., no income data for all years, earnings data not available other than for salaried and casual workers, no information on whether an individual works in the public sector until the 1999 round-the NSS is better than other sources of data and nevertheless allows us to assess whether SCs and STs' labor market outcomes improved as a result of job reservations for them. Job reservations may improve job opportunities for minorities (either because of the reserved public sector jobs themselves or because of other jobs vacated by minorities who would take those reserved

probability model, the error term will be heteroscedastic; I always use robust standard errors clustered at the state-time level. 
jobs). This can generate effects on two margins: (1) the employment margin (moving from not employed to employed, employed to paid employed, and within paid employed from non-salaried job to salaried job); and (2) the quality of job margin conditional on being in a salaried job. The three employment status outcomes can capture the first margin. Wage for salaried workers can capture the second margin.

\section{$5 \quad$ Empirical Analysis}

\subsection{Conceptual Framework}

Theoretically, job reservations for minorities should make minorities no worse off. ${ }^{6}$ This is because more public sector jobs are available to minorities compared to without job reservations, which could improve minorities' labor market outcomes in two ways. The most direct effect is that some minorities will be employed in these reserved jobs, and as I document below public sector employment are on average more attractive than other types of employment. But even some minorities who do not end up getting a reserved job may nonetheless experience benefits. First, through raising the expected benefits from human capital investments (because there is a greater probability of getting a public sector job), job reservations may induce minorities to increase their investments in human capital. Although a job may be reserved for minorities, it will be filled only if there is a qualified candidate, and moreover there may be a great deal of competition among minorities for reserved jobs with lower advertised educational requirements. To improve their chances of getting a reserved job, minorities may invest in preparation for civil service exams or lengthier searches for a better job match in the private sector with the goal of eventually getting a public sector job. Yet these investments will improve their labor market outcomes even if they fall short of securing a public sector job. ${ }^{7}$ Second, job reservations may improve opportunities for minorities even in the private sector. Although

\footnotetext{
${ }^{6}$ In the case in which non-minorities have a comparative advantage in higher level positions and minority labor is complementary with non-minority labor, then it is possible that reserving jobs at all levels will have general equilibrium effects in which there will be fewer jobs overall which hurts everybody. This is unlikely to be a concern in the Indian context since the reservations pertain to public sector employment, where the number of jobs is less responsive to market pressures. Moreover it is not clear among job applicants deemed qualified for a job vacancy whether minorities are less productive than non-minorities.

${ }^{7}$ This raises the question of why minorities do not invest in more human capital even without the job reservations. One possibility is that there is incomplete information about the benefits of human capital investments, and job reservations reduce this information problem. Some of the reserved jobs are extremely attractive, and the lure of a large prize may be what induces minorities to get information about how formal labor markets work and how to succeed in them. A second possibility is discussed next: improved opportunities in the private sector.
} 
private firms are not legally required to diversify, nonetheless they may do so because the job reservation policy changes attitudes about whether minorities can perform modern jobs, or induces public/political pressure on private firms to hire more minorities.

In addition to the foregoing theoretical considerations, how the job reservation policy is implemented will affect its effects. The Indian Constitution spells out the intended job reservation policy to help minorities, but the de facto policy may be different from the de jure policy. The effectiveness of the policy rule can be undermined under the following circumstances. First, if there are few public sector job vacancies available or expected to be available, then the benefit will be small (and unlikely to be detectable in empirical analysis). Second, if there are not enough qualified candidates for reserved jobs (so the reserved jobs are left unfilled), then the benefit will also be small. Public sector jobs range from unskilled to very skilled. Each public sector job has a minimum set of qualifications (including educational requirements, and for some posts, civil service exam scores). Reserved jobs are drawn from all skill levels, and it is possible to imagine that some with high or unusual requirements may not have a qualified candidate. Additionally, spatial mismatch between where most public sector job vacancies are located far and where most minorities would reduce the benefits of the job reservation policy.

In summary, economic theory suggests non-negative effects of reserving jobs for minorities on minorities' labor market outcomes over the minorities' lifetime. There may be temporary periods, though, in which labor market outcomes look worse (e.g., not employed, or employed in a lower-paying job) because minorities are investing in their human capital (e.g., education, exam preparation, training, work experience). How the job reservation policy is implemented will mediate these theoretical effects. Empirical work is needed to see whether, and the extent to which, job reservation policies help minorities.

\subsection{Specification and Identification}

The objective is to estimate the effect of reserving jobs for a targeted group on the labor force outcomes of the targeted group. Suppose the relationship between share of jobs reserved for a particular group and the labor market outcomes of an individual belonging to that group could be approximated as:

$$
y_{i s t}=\alpha_{s}+\beta_{t}+\gamma J \text { obs Reserved } \text { st }+\varphi J_{i s t}+e_{i s t}
$$


where $y_{i s t}$ is the labor market outcome for individual i residing in state s observed at time t. $\alpha_{s}$ is the state fixed effects, and control for any time-invariant state characteristics. $\beta_{t}$ is the time fixed effects, and control for any macroeconomic shocks or national policies that affected everyone uniformly. Jobs Reserved Rt $_{\text {is }}$ the share of public sector jobs reserved for individual i's social group in state s at time t (Each model will be estimated separately for SCs and STs. When the SC sample is used, Jobs Reserved Rt $_{\text {is }}$ the percent of jobs reserved for SCs and analogously when the ST sample is used.). $J_{i s t}$ is a set of individuallevel controls (i.e., age, sex, educational attainment, rural/urban residence, marital status and religion). Finally $e_{i s t}$ is the error term.

The coefficient of primary interest in Equation 1 is $\gamma$, the effect of percent jobs reserved on the labor market outcome. Given the presence of state fixed effects and time fixed effects in the model, $\gamma$ is identified using within-state variation in jobs reserved over time where time effects have been partialled out. $\gamma$ would not be consistently estimated by the ordinary least squares (OLS) if there were an omitted variable not included in this

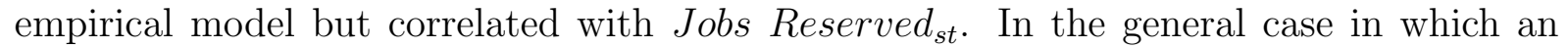
area chooses its own share of jobs reserved, clearly there will be concerns about omitted variable bias. Areas that have more jobs reserved for minorities will likely systematically differ in ways that affect the outcome variables; area fixed effects mitigate this concern to somewhat however there might be time-varying area characteristics that matter, such as changing attitudes about minorities or other changes.

In the case of India, all the variation in the percentage of jobs reserved for SCs and STs in a state is attributable only to changes in their census population estimates. This is attractive for the purpose of identifying $\gamma$ because a state's preferences regarding minorities-

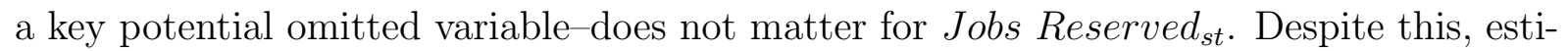
mating Equation 1 using Indian data may lead to a biased estimate of $\gamma$ for the following reason. Minority population share from the census surely determines the share of jobs reserved, but it may affect labor market outcomes in other ways besides through the share of jobs reserved. For example, minority population shares may affect the probability that any one minority member gets a good job or may determine other welfare policies directed at minorities. In order to guard against this source of omitted bias, I expand the set of control variables to include minority population share both from the most recent census and the current year. First, I add Census Pop st, which is individual i's social group's share of the population in the most recent census in state $\mathrm{s}$ at time t. (When the SC 
sample is used, Census Pop st is the census population share for SCs and analogously when the ST sample is used.) I am able to control for the SC and ST census population share because the percent of jobs reserved for SCs and STs is not revised immediately after a new census is taken. Instead, as explained in subsection 3.2, there are several administrative steps that must be taken before percent of jobs reserved are revised to reflect the new SC and ST census population shares. This generates a time lag between when a census is taken and when the percent of jobs reserved is revised, enabling me to

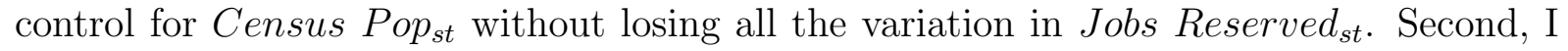

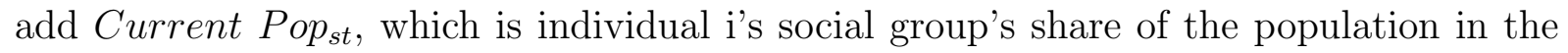
current year. I am able to control for SC and ST current population share because the percent jobs reserved for SCs and STs is driven by their census population count and not their current population count.

In my main empirical work below, I will be estimating the effect of reserving jobs on the employment status of the people in targeted groups. The specific measures of employment status I will use are the probability of being employed, probability of being paid employed ${ }^{8}$, and probability of being salaried conditional on being paid employed (the data and formation of variables are described in the next section). For this analysis, the base specification will be Equation 1 with the addition of the controls for the targeted group's census population share and current population share:

$$
y_{i s t}=\alpha_{s}+\beta_{t}+\gamma \text { Jobs Reserved } \text { st }+\varphi J_{\text {ist }}+\phi \text { Census Pop } \text { Pet }+\delta \text { Current Pop } \text { st }+e_{i s t}
$$

I also estimate a second specification which controls for two state-time-varying variables: state per capita income last year and population density, together denoted by $X_{s t}$ :

$y_{i s t}=\alpha_{s}+\beta_{t}+\gamma$ Jobs Reserved st $+\varphi J_{i s t}+\phi$ Census Pop P $_{s}+\delta$ Current Pop Put $+\eta X_{s t}+e_{i s t}$

It may be useful to control for state per capita income. For example, states with higher income growth may experience differential changes in population growth rates and growth in employment opportunities; if this story is true, then the estimated $\gamma$ in Equation 2 would be reflecting in part the effects of state per capita income.

\footnotetext{
${ }^{8}$ Paid Employment is comprised of salaried, self-employed, and casual workers only.
} 


\subsection{Allowing Effects on Employment Status to Vary by Educa- tion}

The $\gamma$ in Equation 2 or 3 gives the average effect of job reservations for the targeted group on individuals belonging to that targeted group. Is the effect heterogeneous? In the Indian media, there are stories asserting that reservation policies benefit primarily the "creamy layer"-consisting of people who would be doing well even without the reservation policies-rather than the worst-off minorities. In the United States too, there is speculation that affirmative action in admission to educational institutions primarily helps the most able, who presumably would have done well even without the affirmative action. Therefore, it is of interest to test whether the effect of job reservations varies by some measure of individual's human capital or ability. One such measure available in the National Sample Survey is educational attainment.

To proceed, we modify Equations 2 and 3 to include interactions between the treatment variable (Jobs Reserved st $_{\text {) }}$ ) with four dummy variables for educational attainment (primary school, middle school, secondary school, and upper secondary school or higher) that are already elements of $J_{i s t}$. Equation 2 with this modification is given by:

$$
\begin{aligned}
y_{i s t}= & \alpha_{s}+\beta_{t}+\gamma_{0} \text { JobsReserved }_{\text {st }}+\gamma_{1} \text { JobsReserved }_{\text {st }} * \text { PrimarySchool }_{\text {ist }} \\
& +\gamma_{2} \text { JobsReserved }_{s t} * \text { MiddleSchool }_{\text {ist }}+\gamma_{3} \text { JobsReserved }_{\text {st }} *{\text { Secondary } \text { School }_{i s t}} \\
& +\gamma_{4} \text { JobsReserved }_{\text {st }} * \text { HigherSecondary }_{i s t}+\varphi J_{\text {ist }}+\phi \text { CensusPop }_{\text {st }} \\
& + \text { SCurrentPop }_{\text {st }}+e_{\text {ist }}
\end{aligned}
$$

where the omitted educational attainment category is "no schooling". Thus, $\gamma_{0}$ gives the effect of job reservation for people with no schooling. The other $\gamma \mathrm{s}$ give the effect relative to people with no schooling. Similarly, Equation 3 changed to allow effects to differ by education is:

$$
\begin{aligned}
y_{i s t}= & \alpha_{s}+\beta_{t}+\gamma_{0} \text { JobsReserved }_{\text {st }}+\gamma_{1} \text { JobsReserved }_{\text {st }} * \text { PrimarySchool }_{\text {ist }} \\
& +\gamma_{2} \text { JobsReserved }_{s t} * \text { MiddleSchool }_{\text {ist }}+\gamma_{3} \text { JobsReserved }_{\text {st }} * \text { SecondarySchool }_{\text {ist }} \\
& +\gamma_{4} \text { JobsReserved }_{s t} * \text { HigherSecondary }_{i s t}+\varphi J_{\text {ist }}+\phi \text { CensusPop }_{\text {st }} \\
& + \text { SCurrentPop }_{s t}+\eta X_{\text {st }}+e_{i s t}
\end{aligned}
$$




\subsection{Allowing Effects on Employment Status to Vary by Sector and Gender}

I will also test whether the effect of reserving jobs for minorities varies by the individual's sector (urban/rural) and gender. First, there are more public sector jobs in urban areas than rural areas. Thus, members of SCs and STs living in urban areas may be more likely to have a reserved job become available that suits them. Second, in India many characteristics differ between males and females (e.g., employment rate, educational attainment, social status) and it is quite possible that the responsiveness of labor market outcomes to job reservations also differ by sex. Even in the U.S., there is evidence that employment-related affirmative action may have different impacts by sex. For example, a number of studies including Ashenfelter and Heckman (1976) and Smith and Welch (1976) compare the shares of employment or employment growth accounted for by different demographic groups between establishments that practice affirmative action and those who do not. They all find a positive impact on black male's share of total employment, while there is no such consensus on effects for black females.

We can estimate Equation 3 separately for each of the four sector-gender combinations to assess whether the effects vary by sector and gender. It turns out the following specifications with additional constraints produce similar results, so I will use them below. The following specification modifies Equation 3 to allow the effects of percent jobs reserved to vary by sector and gender:

$$
\begin{aligned}
y_{\text {ist }}= & \alpha+\gamma_{0} \text { JobsReserved }_{\text {st }}+\gamma_{1} \text { JobsReserved }_{\text {st }} * \text { Male }_{i s t} * \text { Rural }_{\text {ist }} \\
& +\gamma_{2} \text { JobsReserved }_{\text {st }} * \text { Female }_{i s t} * \text { Urban }_{i s t} \\
& +\gamma_{3} \text { JobsReserved }_{\text {st }} * \text { Female }_{i s t} * \text { Rural }_{i s t}+\tau Q+e_{i s t}
\end{aligned}
$$

where Q includes state dummies, time dummies, age, age squared, married dummy, sector dummy, gender dummy, education dummies, religion dummies, ST (SC) census population share, ST (SC) current population share, state per capita income, and population density; all of which are allowed to vary by gender and sector. 


\subsection{The Impact of Job Reservation on Wages of Salaried Work- ers}

Job reservations for minorities may affect not only minorities' employment status but also the quality of their job given the same employment status. As I elaborate on in the next section, the different categories of employment status may be ranked as (from worse to better): not working, working, working for pay, and working in a salaried job. Public sector jobs belong to the latter category, and are among the better jobs in that category. Since there is heterogeneity among jobs within the salaried category, it would be interesting to test whether, conditional on having a salaried job, the wages are higher. To address this possibility, we perform the following analysis:

$$
W_{s t}=\alpha_{s}+\beta_{t}+\gamma \text { JobsReserved }_{s t}+\phi \text { CensusPop }_{s t}+\delta \text { CurrentPop }_{s t}+\eta X_{s t}+e_{s t}
$$

where $W_{s t}$ is in turn the log wage at the mean and at the following percentiles: $10^{\text {th }}, 25^{\text {th }}$, $50^{t h}, 75^{t h}, 90^{t h}$. The analysis described by Equation 7 uses state-time cells (individual level data on wages are aggregated to the state-time level). This is necessary because among the outcomes are wages at different points of the wage distribution for state $\mathrm{s}$ at time t; such statistics are inherently group, not individual, data. These outcomes are useful to understanding which minorities gain from the job reservation policy: all salaried workers, low-paid salaried workers, or high-paid salaried workers? It is worth repeating here that each model is estimated separately for SCs and STs. When the SC sample is used, $W_{s t}$ is calculated only using SC salaried workers and analogously when the ST sample is used.

\subsection{The Impact of Job Reservation on Monthly Per Capita Ex- penditure}

We may wish to get a summary outcome measure that encapsulates all the effects of job reservations for minorities on minorities' well-being, including but not limited to changes in employment status and changes in wages conditional on having a salaried job. Unfortunately in the National Sample Survey, there is not a measure of income, and wages are reported only for a few employment categories. To estimate the impact of job reservation on the well-being of SCs and STs therefore, I use the individual's household's 
monthly per capita expenditure (MPCE) as an outcome variable. Many SCs and STs are close to the poverty line and have no access to financial institutions, so MPCE is interesting not only as a measure of consumption but also as a proxy for income. The analysis is similar to what was described for wages in the previous subsection with the following key difference: the MPCE analysis can include all people, not only salaried workers since MPCE is available for all households. The estimating equation is:

$$
M P C E_{s t}=\alpha_{s}+\beta_{t}+\gamma J_{o b s R e s e r v e d}+\phi \text { CensusPop }_{s t}+\delta \text { CurrentPop }_{s t}+\eta X_{s t}+e_{s t}
$$

where $M P C E_{s t}$ is in turn the $\log$ MPCE at the mean and at the following percentiles: $10^{\text {th }}, 25^{\text {th }}, 50^{\text {th }}, 75^{\text {th }}, 90^{\text {th }}$. All variables are at state-time level.

\section{Main Results}

First, I present the results of estimating Equations 2 and 3 using OLS for each of the three employment status outcomes. I focus my discussion on the coefficient for the job reservation variable, which gives the average effect of percent jobs reserved. Table 5 reports the results for the STs and Table 6 reports the results for the SCs. Columns (1)(2) of Table 5 suggest that increases in percent jobs reserved for STs has no impact on the probability of being employed. Columns (3)-(4) examine the impact of ST job reservation policy on probability of being paid employed. ST job reservation does not affect the probability of working for pay at conventional levels of significance ( 5 percent or better) but does have a positive impact that is significant at the 10 percent level in column (4). Finally, columns (5)-(6) suggest that there is no effect of ST job reservation on the probability of having a salaried job conditional on being in paid employment. The finding that ST job reservation had essentially no impact on ST employment status outcomes is not surprising due to the following reasons. First, the educational attainment among STs is much lower compared to other social groups, and many reserved jobs may not have qualified candidates. Second, STs primarily reside in rural areas while the majority of the salaried jobs are in urban areas.

Table 6 shows the average effect of percent jobs reserved for SCs on SC employment status outcomes. Columns (1)-(4) suggest that there is no significant effect on either the probability of working or the probability of working for pay. In columns (5)-(6) we observe 
that increases in percentage of jobs reserved for SC has a significant positive impact on the likelihood of getting a salaried job conditional on being in paid employment. The column (6) estimate suggests that a 1-percentage point increase in SC job reservation increases the probability of being in a salaried job conditional on being in paid employment by 0.6 percentage points. Taken together, Table 6 suggests that the job reservations are causing SCs who are already in paid employment shift to better (salaried) jobs; SCs who are not in paid employment do not appear to be affected.

Second, I present the results where I allow the effect of minority job reservation on employment status outcomes to vary by education, i.e., I estimate Equations 4 and 5. Table 7 reports the results for the STs and Table 8 reports the results for the SCs. In Table 7, none of the effects of ST job reservation are significant at the 5 percent level or better. It is interesting to note that in columns (1)-(2), for the most educated people, there is a negative impact on the probability of working that is significantly different from the effect on the uneducated at the 10 percent level. Perhaps not much should be made of this result, however this result is consistent with people who can potentially qualify for the best public sector jobs withdrawing from the labor market to prepare for the civil service exams required for those jobs. That is, the long run prize of the best public service jobs is inducing unemployment in the short run. Obviously, most minorities cannot afford to do this, but it must be said that STs with higher secondary education or higher are rare (according to Table 3, they make up less than 3 percent of all STs in the sample).

Table 8 reports the effect of SC job reservation on SC employment by education. From columns (1)-(2) of Table 8, increases in SC job reservation has significant negative impact on probability of being employed for the uneducated, with the negative effect diminishing as education increases. Similar comments can be made about the effects on being in paid employment reported in columns (3)-(4). Columns (5)-(6) examine the impact of SC job reservation on probability of getting a salaried job conditional on being paid employed. Increases in SC job reservation has significant positive impact on this outcome for the uneducated, with the positive impact diminishing as education increases. The column (6) estimate suggests that a 1-percentage point increase in SC job reservation increases the likelihood that an uneducated SC get a salaried job conditional on being in paid employment by 0.9 percentage points. In light of the positive effects for the less educated in columns (5)-(6), it is possible to build an intuition for the negative effects in columns (1)-(4). In particular, getting a salaried job is a lucrative prize, but it is not easy for 
minorities to get one. Increases in jobs reserved for SCs increase the chance of obtaining that prize, and may induce SCs outside of paid employment to take a longer time to prepare or search for a good job. Additionally, it makes sense that we detect positive effects on $\operatorname{Pr}$ (Salaried|PaidEmp) for the less educated but not for the more educated. This outcome is only a blunt measure of job quality. Educated individuals can get a salaried job relatively easily, and failing to detect impacts on the employment status outcomes on educated people does not necessarily mean they did not benefit. Instead, we will have to look at additional outcomes: wages for salaried workers and MPCE for everyone.

Before moving to the wage and MPCE analysis, I consider whether the effects of job reservation are heterogeneous by sector and gender, i.e., I estimate Equation $6{ }^{9}$ Table 9 reports the estimated effects of ST job reservation on ST employment status outcomes. The effect on $\operatorname{Pr}($ Employed $)$ and $\operatorname{Pr}$ (Salaried|PaidEmp) is not significant for any of the four sector-gender categories. The effect on $\operatorname{Pr}($ PaidEmp) is not significant for men, but is positive and significant for women. Thus, ST job reservations appear to be benefiting working women: they are more likely to be in paid employment, with the composition of paid employment unchanged.

Table 10 reports the effect of minority job reservation on employment outcomes for the SCs. Columns (1)-(2) show that effects on employment and paid employment are negative except for rural males. Column (3) shows that it is SCs in urban areas are experiencing the positive effect of job reservation on the probability of getting a salaried job conditional on being in paid employment. Effects on $\operatorname{Pr}$ (Salaried|PaidEmp) are similar for male SCs and female SCs: in rural areas, there are no effects for both, and in urban areas, there are positive effects for both.

Next, I estimate the effect of job reservations on the wages of salaried workers. As discussed above, the three employment status outcomes do not capture the changes in wellbeing associated with changes in job quality given the same employment status. Within the category of salaried jobs, there are better jobs and worse jobs, and it is of interest to test whether job reservations changed the quality of jobs that SCs and STs hold. SCs and STs hold a small share of all salaried jobs, so we may learn something about the quality of salaried jobs they hold by examining the wages earned by SC and ST salaried workers. The methodology is described in subsection 4.5, with the specification given by Equation

\footnotetext{
${ }^{9}$ The results from estimating Equation 6 are similar from the results from estimating Equation 3 for each of the four sector-gender categories.
} 
7. Note that the unit of analysis is the state-time cell. I only do this analysis for urban males because for them, there are a reasonable number of observations per cell. There are much fewer salaried workers among women and rural residents. Table 11 shows the results for STs and Table 12 shows them for SCs. There are no significant effects of minority job reservation on wages at the mean and at all the different points of the wage distribution. I have repeated the analysis dividing the sample into two education groups-high (secondary and higher secondary or higher) and low (uneducated, primary and middle)-and still find no effects. Thus, there is no evidence of "job upgrading" within salaried jobs at least as measured by wages in the NSS (the NSS asks about wages earned in the last week). It remains possible, though, that the salaried job is better along non-monetary dimensions (e.g., prestige, perks, job security) and perhaps even monetary dimensions to the extent that the NSS wage measure is a poor measure of total compensation.

Finally, I estimate the effect of job reservations on the monthly per capita expenditure. This can be viewed as a summary measure of well-being, capturing any changes in employment status and any changes in wages conditional on employment status. MPCE is available for all households, so all employment categories can be included for analysis. The methodology is described in subsection 4.6, with the specification given by Equation 8. The unit of observation is again the state-time cell. Again, I use urban males but results are similar for urban females. I do not find any effect of ST job reservation on ST MPCE, either for the full sample or after dividing the sample by education (Table 13 reports the estimated results for high and low educated STs). I do not find an effect of SC job reservation on SC MPCE when the full sample is used, however when I perform the analysis separately for the high educated and low educated, significant positive effects on MPCE are detected for the low educated. This is shown in Table 14. Given that there was no effect of SC job reservation on wages (Table 12), then these effects on MPCE must be the consequence of the effect of SC job reservation on the probability of having a salaried job (Table 6). It makes sense that the less educated experience the gains in MPCE since it was the less educated who experienced the gains in the probability of having a salaried job (Table 8).

The main findings from Tables 5-14 may be summarized as follows. First, SC benefitted from SC job reservation policy while ST did not benefit at the conventional level of significance at least using the labor market outcome measures available in the NSS. Specifically for SC, I do not find an overall change in employment, but find changes in the 
composition of employment-more SCs are getting salaried jobs. Second, the benefits of $\mathrm{SC}$ job reservation were more pronounced for SCs in urban areas and for the less educated.

\section{Robustness Checks and Credibility of Results}

\subsection{Instrumental Variable Estimation of the Impact of Job Reser- vation}

In this section of the paper, I use an instrument to estimate the causal effect of minority job reservation on employment outcomes. My identification relies on withinstate variation in minority job reservation over time and the exogenous timing of the year when the job reservation for minorities is revised. The underlying assumption is that the time lag between the arrival of new census population estimates and the year when job reservation for minorities is revised is completely exogenous. If this assumption is not true, then the estimated coefficient for the job reservation variable would not have a causal interpretation. ${ }^{10}$

To address the possibility that the job reservation variable is endogenous, I use an instrumental variables strategy. I use political reservation for minorities to instrument for the minority job reservation variable. In order for minority political reservation to be a valid instrument, it should be correlated with the endogenous variable and uncorrelated with the error term. Pande (2003) provides evidence that the minority political reservation to be correlated with the job reservation variable. It might be a valid exclusion restriction because it is based on a strict policy rule (in a state, percent of legislative seats reserved for minorities is equal to the minority population share according to the most recent census) that is implemented with a lag not subject to any discretion (after new census estimates arrive, new political reservations become effective with the next election year). ${ }^{11}$ The first stage regression (estimated separated for ST and SC) is:

$$
\begin{aligned}
\text { MinorityJobReservation }_{s t}= & \alpha_{s}+\beta_{t}+\gamma \text { MinorityPoliticalReservation }_{s t} \\
& +\varphi J_{\text {ist }}+\phi \text { CensusPop }_{\text {st }}+\delta \text { CurrentPop }_{s t} \\
& +\eta X_{s t}+e_{i s t}
\end{aligned}
$$

\footnotetext{
${ }^{10}$ It should be noted that conversations I had with bureaucrats during my data collection trip to India in Summer 2006 do not suggest that the timing was endogenous; administrative lags appeared to be the sole determinant of the timing.

${ }^{11}$ See Pande (2003) and Prakash (2007) for more information on India's political reservation policy.
} 
The second stage is Equation 3.

Results from estimating Equation 9 using OLS and Equation 3 using two-stage least squares (2SLS) are reported in Table 15. The endogenous regressor is ST (SC) job reservation and the identifying instrument is ST (SC) political reservation. For both STs and $\mathrm{SCs}$, in the first stage, minority political representation is a strong predictor of minority job reservation so weak instruments is not a concern here. Panel A displays the results for STs and Panel B displays them for the SCs. None of the 2SLS effects are significant since the standard errors are considerably larger (since so much of the variation in percent jobs reserved is no longer used). However, the point estimates are consistent with our earlier results: a positive effect on the probability of being in a salaried job conditional on being in paid employment that is larger for SCs than STs. This result also suggests that there is little bias from omitted variables in the ordinary least squares estimate of the effect of minority job reservation on employment outcomes; suggesting omitted variables in the structural equation are weakly correlated or uncorrelated with minority job reservation

\subsection{Control Experiment using Non-Minorities}

In this section of robustness check, I use a control experiment to test for state-specific time effects. We might be concerned that the estimated coefficients for the job reservation variable does not reflect the true causal effect of job reservation but instead includes the effects of omitted state-time variables. We might test for state-specific time effects by using a group of people that experience the same state-time conditions but are not eligible for reserved jobs: the non-minorities. In particular, I estimate the effect of ST job reservation on the employment status outcomes of non-SC/ST (see Appendix Table C-1); these specifications are the same as the Table 4 ones except in Appendix Table $\mathrm{C}-1$, the individuals in the sample have not received a real treatment (non-SC/ST are not impacted by ST job reservations). Similarly, I estimate the effect of SC job reservation on the employment status outcomes of non-SC/ST (see Appendix Table C-2); these specifications are the same as the Table 5 ones. I do not find any significant effect of ST job reservation on probability of being employed and probability to being paid employed for non SC/ST [columns (1)-(4)]. However, I do find significant negative effect of ST job reservation on probability of being salaried conditional on being in paid employment for the non SC/ST. So increases in percent jobs reserved for ST is associated with decreases 
in $\operatorname{Pr}($ Salaried|PaidEmp) for reasons having nothing to do with the job reservations policy itself. Thus, if we imagine removing this secular state-time effect (taking the Table 4 estimate and subtracting out the corresponding Appendix Table C-1 estimate), then the effect on STs would be positive. In Table C-2, I do not find any significant effect of SC job reservation on the three employment status outcomes for the non-SC/ST. This supports the interpretation of the coefficients for $\mathrm{SC}$ job reservation in the rest of the paper as due to $\mathrm{SC}$ job reservation rather than omitted state-time variables.

\section{Discussion}

Using an identification strategy based on jumps and administrative lags in the response of minority job reservation to population changes in India, I find that minority job reservations have varied effects on minority labor market outcomes. First, I find that job reservations significantly improve job outcomes for scheduled castes but not scheduled tribes. Second, among the scheduled castes, benefits accrue primarily to members who reside in urban areas and are less educated. These benefits appear to be in the form of moving up the job ladder to salaried positions from other types of paid employment. Indeed, it does not appear that there are increases in the probability of being employed or being in paid employment; if anything, these probabilities tend to be negative, suggesting that the job reservations may be inducing minorities to invest in longer job searches. Nor does it appear that among salaried workers, job reservations raise the wages. Given the positive effect on the propensity of urban and less-educated SCs to get a salaried position, not surprisingly SC job reservation has a positive effect on the monthly per capita expenditures of urban and less-educated especially at the lower half of the distribution. Thus, my analysis suggests that India's job reservation policy benefited SCs overall, but not STs overall. Although scheduled tribes and scheduled castes both have much worse socioeconomic outcomes than non-minorities in India, the findings suggest that distinct policies for each minority group may be needed to narrow the gaps.

That members of scheduled tribes do not benefit overall may be due to their concentration in remote rural areas; according to the 2001 Census, over 90 percent of the ST population lives in rural areas. Yet, most new vacancies in public sector employment jobs are in urban areas. Thus, there is a spatial mismatch between where STs live and where reserved jobs are. This spatial mismatch problem appears to be present for the SCs living 
in rural areas as well, which is probably they did not benefit from the job reservations either. Considering that rural areas contain 72 percent of the population in the 2001 Census and an even larger share of the country's poor, it seems clear that job reservations is not be a policy that can promote economic progress for most of the country's neediest.

It is interesting that SCs with secondary education and higher do not seem to be affected by the job reservations. Job reservations cover a full range of public sector jobsfrom less skilled to very skilled-so some reserved jobs should be attractive to the more educated. One interpretation of the insignificant effect for more educated SCs on the probability of being in a salaried position conditional on being in paid employment, wages for male urban salaried workers, and MPCE for urban residents is that there truly is no effect. Perhaps reserved jobs at the highest skill level go unfilled because applicants are not deemed qualified, or because the few SCs who would be qualified for them have even better employment opportunities in the private sector. Even though there may not be legal mandates for private firms to hire minorities, they are encouraged to do so, and it is possible that they compete for the few highly qualified minorities. Another interpretation is that the educated SCs are benefiting, but such benefits are not captured by the outcomes I have used; for example, perhaps job reservations improve non-financial aspects of the job.

Other countries have used or are considering using mandated employment quotas, so the results here for India's job reservation policy may be applicable. But even in a single country, there are heterogeneous effects of job reservation. In the short run, for job reservations to have a beneficial effect, it seems important to match the location and skill requirement of the reserved jobs to attributes of the targeted population. In the longer run, perhaps there will be changes in investments in human capital and mobility in response to the job opportunities created by the job reservations. Along these lines, it would be interesting to estimate the effect of job reservations on minorities' mobility; in India, there is very little geographic mobility especially across states, but perhaps there is an impact on rural-urban migration. Another interesting extension is the impact of job reservations on human capital investments. Job reservations raise the expected benefits from human capital investments (because there is an increased chance of getting a good job). First, do adults invest more in adult education and useful work experience? In this paper, we find that job reservations sometimes reduce the probability of being employed, which is consistent with adults investing in their human capital (perhaps preparing for 
exams to enable a better job match later, or searching for a job that is either in the public sector or provides a better stepping stone for a public sector job) but more direct evidence would be useful. Second, do parents invest more in the schooling of their children because of the larger expected returns to children's schooling due to the job reservations? If there are indeed such intergenerational effects, then the benefits of reserving jobs for minorities would be greater than what has been reported in this paper. 


\section{References}

Ashenfelter, Orley., Heckman, James J. "Measuring the Effect of an Antidiscrimination Program," in Orley Ashenfelter and James Blum, eds.,Evaluating the Labor-Market Effects of Social Programs, Princeton: Industrial Relations Section, Princeton University, Research Report Series No. 120, 1976, pp. 46-84.

Bell, Jr. Duran. "Bonuses, Quotas, and the Employment of Black Workers" The Journal of Human Resources, Summer 1971, 6 (3), pp. 309-320.

Beller, Andrea H. "The Economics of Enforcement of An Antidiscrimination Law: Title VII of the Civil Rights Act of 1964" Journal of Law and Economics, October 1978, 21 (2), pp. 359-380.

Bertrand, Marianne; Duflo, Esther and Sendhil Mullainathan. "How Much Should We Trust Differences-In-Differences Estimates?." Quarterly Journal of Economics, February 2004, 119 (1), pp 249-275.

Bertrand, Marianne; Hanna, Rema and Sendhil Mullainathan. "Affirmative Action in Education: Evidence From Engineering College Admissions in India." NBER Working Paper 13926, April 2008.

Brown, Charles. "Black-White Earnings Ratios Since the Civil Rights Act of 1964: The Importance of Labor Market Dropouts" Quarterly Journal of Economics, February 1984, 99 (1), pp. 31-44.

Chattopadhyay, Raghabendra., Duflo, Esther. "Women as Policy Makers: Evidence from a Randomized Policy Experiment in India" Econometrica, September 2004, 72 (5), pp. 1409-1443.

Coate, Stephen and Loury, Glenn C. "Will Affirmative-Action Policies Eliminate Negative Stereotypes?" The American Economic Review, December 1993, 83 (5), pp $1220-40$.

Donohue, John J. III., Heckman, James J. "Continuous Versus Episodic Change: The Impact of Civil Rights Policy on Economic Status of Blacks" Journal of Economic Literature, December 1991, 29 (4), pp. 1603-1643. 
Duflo, Esther. "Why Political Reservations?" Journal of the European Economic Association, 3 (2-3), pp. 668-678.

Eapen, Mridul. "Trends in Public Sector Employment and Earnings: Part One" Social Scientist, March 1980, 8 (8), pp. 3-21.

Eapen, Mridul. "Trends in Public Sector Employment and Earnings: Part Two" Social Scientist, May 1980, 8 (10), pp. 38-51.

Election Commission of India. "Statistical Reports of Assembly Elections", New Delhi, India, 1981-2000.

Freeman, Richard B. "Changes in the Labor Market for Black Americans, 1948-1972" Brookings Papers on Economic Activity, 1973, 1973 (1), pp. 67-131.

Galanter, Marc. "Competing Equalities: Law and the Backward Classes in India", Berkeley, CA: University of California Press, 1984.

Government of India. "National Sample Survey Organization: Employment and Unemployment Round", New Delhi, India, 1983-84, 1987-88, 1993-94, 1999-00.

Holzer, Harry J., Neumark, David. "Assessing Affirmative Action" NBER Working Paper 7323, August 1999.

Holzer, Harry J., Neumark, David. "Are Affirmative Action Hires Less Qualified? Evidence from Employer-Employee Data on New Hires" Journal of Labor Economics, 1999, 17 (3), pp. 534-569.

Holzer, Harry J., Neumark, David. "What does Affirmative Action do?" Industrial and labor Relations Review, January 2000, 53 (2), pp. 240-271.

Justin, McCrary. "The Effect of Court-Ordered Hiring Quotas on the Composition and Quality of Police" The American Economic Review, March 2007.

Leonard, Jonathan S. "Employment and Occupational Advance Under Affirmative Action" The Review of Economics and Statistics, August 1984, 66 (3), pp. 377-385.

Leonard, Jonathan S. "The Impact of Affirmative Action on Employment" Journal of Labor Economics, October 1984, 2 (4), pp. 439-463. 
Leonard, Jonathan S. "Affirmative Action as Earnings Redistribution: The Targeting of Compliance Reviews" Journal of Labor Economics, July 1985, 3 (3), pp. 363-384.

Leonard, Jonathan S. "Women and Affirmative Action" The Journal of Economic Perspectives, Winter 1989, 3 (1), pp. 61-75.

Leonard, Jonathan S. "The Impact of Affirmative Action Regulation and Equal Employment Law on Black Employment" The Journal of Economic Perspectives, Autumn 1990, 4 (4), pp. 47-63.

Loury, Glenn C. "Is Equal Opportunity Enough" The American Economic Review, May 1981, 71 (2), pp. 127-126.

Myers, Caitlin. "A Cure for Discrimination? Affirmative Action and the Case of California Proposition 209" Industrial and Labor Relations Review, April 2007, 60 (3), pp. 379396.

Office of the Registrar General and Census Commissioner. "Census of India", New Delhi, India, 1981, 1991.

Pande, Rohini. "Can Mandated Political Representation Increase Policy Influence for Disadvantaged Minorities? Theory and Evidence from India" The American Economic Review, September 2003, 93 (4), pp. 1132-1151.

Prakash, Nishith. "Does Political Reservation for Minorities Reduce Poverty? Evidence from India" University of Houston Mimeo, 2007.

Sakthivel, S., Joddar, Pinaki. "Unorganized Sector Workforce in India: Trends, Patterns and Social Security Coverage" Economic and Political Weekly, May 27 2006, pp. $2107-2114$.

Scheduled Caste and Scheduled Tribe Commission. "Annual Scheduled Caste and Scheduled Tribe Commissioners Report", New Delhi, India, 1981-2000.

Smith, James P. "Affirmative Action and the Racial Wage Gap" The American Economic Review, May 1993, 83 (2), pp. 79-84.

Smith, James P., Welch, Finis. "Affirmative Action and Labor Markets" Journal of Labor Economics, April 1984, 2 (2), pp. 269-301. 
Smith, James P., Welch, Finis "Black Economic Progress After Myrdal" Journal of Economic Literature, June 1989, 27 (2), pp. 519-564.

Thorat, Sukhadeo "Caste, Exclusion and Poverty" IIDS Working Paper, 2005.

Wallace, Phyllis A. "Equal Employment Opportunity and the AT\&T Case, Cambridge: MIT Press" 1976.

Welch, Finis. "Employment Quotas for Minorities" The Journal of Political Economy, August 1976, 84 (4), pp. 105-139.

Welch, Finis. "Affirmative Action and Its Enforcement" The American Economic Review, May 1981, 71 (2), pp. 127-133. 
Table 1: Legal Identification of Scheduled Castes and Scheduled Tribes Based on Census

\section{Selection criteria for Scheduled Castes}

1. Cannot be served by clean Brahmans

2. Cannot be served by barbers, water-carriers, tailors, etc who serve the caste Hindu

3. Pollutes a high-caste Hindu by contact or by proximity

4. Is one from whose hands a caste Hindu cannot take water

5. Is debarred from using public amenities, such as roads, ferries, wells or schools

6. Is debarred from the use of Temples (place of worship)

7. Will not be treated as an equal by high-caste men of the same educational qualification in ordinary social intercourse

8. Is merely depressed on account of its own ignorance, illiteracy or poverty and, but for that, would be subject to no social disability

9. Is depressed on account of the occupation followed and whether, but for that, occupation it would be subject to no social disability

\section{Selection criteria for Scheduled Tribes}

1. Tribal origin

2. Primitive way of life and habitation in remote and less accessible areas

3. General backwardness in all respects

Notes: The above criteria were the criteria for the selection of "scheduled castes" and "scheduled tribes" groups as stated in Constitutional orders of 1950. 
Table 2: Economic Characteristics of Scheduled Castes and Scheduled Tribes

\begin{tabular}{llll}
\hline \hline & & & \\
Variable & Scheduled Tribes & Scheduled Castes & Non-SC/ST \\
\hline All India Population Share & 7.9 & 16.4 & 75.4 \\
Within-group characteristics: & & & \\
Infant Mortality Rate* (age 0-5 yrs) & 121 & 118 & 80 \\
Literacy Rate (Rural) & 45 & 51 & 63 \\
Literacy Rate (Urban) & 69 & 68 & 82 \\
School Enrollment (age 7-17 yrs) & 56.3 & 65.7 & 81.3 \\
Rural Poverty Headcount Ratio & 46 & 36 & 21 \\
Urban Poverty Headcount Ratio & 35 & 38 & 21 \\
\hline \hline
\end{tabular}

The sources for this data (1990's) are NSSO, Census of India, Thorat (2005) and SC and ST Commissioner's Report.

* Per 1000 children under age 5 .

Table 3: Descriptive Statistics- All India

\begin{tabular}{llll}
\hline \hline & & & \\
Variable Name & Scheduled Tribes & Scheduled Castes & Non SC/ST \\
\hline Dependent Variables: & & & \\
Pr(Employed) & 76.77 & 66.84 & 60.60 \\
& $(0.42)$ & $(0.47)$ & $(0.48)$ \\
Pr(Paid Employment) & 59.63 & 60.42 & 48.49 \\
& $(0.49)$ & $(0.49)$ & $(0.49)$ \\
Pr(Salaried|Paid Employment) & 12.11 & 16.31 & 26.98 \\
Policy Variable: & $(0.33)$ & $(0.37)$ & $(0.44)$ \\
Percent Jobs Reserved & & & \\
Educational Attainment Control Variables: & $(6.77)$ & 17.07 & None \\
High Secondary & 2.77 & $(5.23)$ & $(-)$ \\
& $(0.16)$ & 3.34 & \\
Secondary & 2.53 & $(0.18)$ & 10.66 \\
& $(0.16)$ & 3.31 & $(0.31)$ \\
Middle & 4.99 & $(0.18)$ & $(0.73$ \\
& $(0.22)$ & 6.80 & 8.85 \\
Primary & 11.50 & $(0.25)$ & $(0.28)$ \\
& $(0.32)$ & 13.25 & 17.64 \\
No Education & 78.20 & $(0.34)$ & $(0.38)$ \\
& $(0.41)$ & 73.29 & 56.11 \\
\hline \hline
\end{tabular}

Table continues on next page. 
Table 3: Descriptive Statistics- All India (Continued)

\begin{tabular}{|c|c|c|c|}
\hline Variable Name & Scheduled Tribes & Scheduled Castes & Non SC/ST \\
\hline \multicolumn{4}{|l|}{ Religion Control Variables: } \\
\hline Hinduism & $\begin{array}{l}91.90 \\
(0.27)\end{array}$ & $\begin{array}{l}92.64 \\
(0.26)\end{array}$ & $\begin{array}{l}76.46 \\
(0.42)\end{array}$ \\
\hline Islam & $\begin{array}{l}1.39 \\
(0.12)\end{array}$ & $\begin{array}{l}0.91 \\
(0.09)\end{array}$ & $\begin{array}{l}17.30 \\
(0.38)\end{array}$ \\
\hline Christianity & $\begin{array}{l}4.38 \\
(0.20)\end{array}$ & $\begin{array}{l}1.32 \\
(0.11)\end{array}$ & $\begin{array}{l}2.22 \\
(0.15)\end{array}$ \\
\hline Sikhism & $\begin{array}{l}0.33 \\
(0.06)\end{array}$ & $\begin{array}{l}3.74 \\
(0.19)\end{array}$ & $\begin{array}{l}2.74 \\
(0.16)\end{array}$ \\
\hline Jainism & $\begin{array}{l}0.07 \\
(0.03)\end{array}$ & $\begin{array}{l}0.00 \\
(0.01)\end{array}$ & $\begin{array}{l}0.58 \\
(0.08)\end{array}$ \\
\hline Buddhism & $\begin{array}{l}0.15 \\
(0.04)\end{array}$ & $\begin{array}{l}1.07 \\
(0.10)\end{array}$ & $\begin{array}{l}0.42 \\
(0.07)\end{array}$ \\
\hline Zoroastrianism & $\begin{array}{l}0.00 \\
(0.00)\end{array}$ & $\begin{array}{l}0.00 \\
(0.00)\end{array}$ & $\begin{array}{l}0.00 \\
(0.01)\end{array}$ \\
\hline \multicolumn{4}{|l|}{ Other Control Variables: } \\
\hline Marital Status & $\begin{array}{l}85.85 \\
(0.35)\end{array}$ & $\begin{array}{l}84.87 \\
(0.36)\end{array}$ & $\begin{array}{l}79.81 \\
(0.40)\end{array}$ \\
\hline Male & $\begin{array}{l}49.56 \\
(0.50)\end{array}$ & $\begin{array}{l}50.25 \\
(0.50)\end{array}$ & $\begin{array}{l}50.44 \\
(0.49)\end{array}$ \\
\hline Urban Sector & $\begin{array}{l}14.13 \\
(0.35)\end{array}$ & $\begin{array}{l}27.12 \\
(0.44)\end{array}$ & $\begin{array}{l}39.82 \\
(0.49)\end{array}$ \\
\hline Age & $\begin{array}{l}28.55 \\
(6.68)\end{array}$ & $\begin{array}{l}28.46 \\
(6.74)\end{array}$ & $\begin{array}{l}28.61 \\
(6.67)\end{array}$ \\
\hline Census population share & $\begin{array}{l}13.55 \\
(7.53)\end{array}$ & $\begin{array}{l}16.56 \\
(5.29)\end{array}$ & $\begin{array}{l}74.21 \\
(7.28)\end{array}$ \\
\hline Current population share & $\begin{array}{l}13.80 \\
(7.40)\end{array}$ & $\begin{array}{l}17.73 \\
(5.36)\end{array}$ & $\begin{array}{l}75.46 \\
(7.34)\end{array}$ \\
\hline Census population density & $\begin{array}{l}206.33 \\
(124.00)\end{array}$ & $\begin{array}{l}291.45 \\
(149.21)\end{array}$ & $\begin{array}{l}272.68 \\
(150.48)\end{array}$ \\
\hline $\operatorname{Lag}(1) \mathrm{SDP}$ & $\begin{array}{l}8.88 \\
(1.94)\end{array}$ & $\begin{array}{l}9.08 \\
(1.98)\end{array}$ & $\begin{array}{l}8.95 \\
(1.99)\end{array}$ \\
\hline
\end{tabular}

Data consists of men and women aged 18-40 living in India from the 1983, 1987, 1994 and 1999 rounds of the National Sample Survey who are not currently attending school. SDP indicates state domestic product. 
Table 4: Average Monthly Wage and Consumption by Employment Category, Urban Men

\begin{tabular}{|c|c|c|c|c|c|c|}
\hline & \multicolumn{2}{|c|}{$\underline{\text { ScheduledTribe }}$} & \multicolumn{2}{|c|}{$\underline{\text { ScheduledCaste }}$} & \multicolumn{2}{|c|}{ NonSC/ST } \\
\hline & Wage & MPCE & Wage & MPCE & Wage & MPCE \\
\hline \multicolumn{7}{|l|}{ Employment Category: } \\
\hline Employed & $\begin{array}{l}\text { NA } \\
(-)\end{array}$ & $\begin{array}{l}710 \\
(529)\end{array}$ & $\begin{array}{l}\text { NA } \\
(-)\end{array}$ & $\begin{array}{l}637 \\
(394)\end{array}$ & $\begin{array}{l}\text { NA } \\
(-)\end{array}$ & $\begin{array}{l}866 \\
(613)\end{array}$ \\
\hline Salaried & $\begin{array}{l}4077 \\
(3464)\end{array}$ & $\begin{array}{l}956 \\
(638)\end{array}$ & $\begin{array}{l}3023 \\
(2791)\end{array}$ & $\begin{array}{l}797 \\
(498)\end{array}$ & $\begin{array}{l}3446 \\
(3611)\end{array}$ & $\begin{array}{l}1004 \\
(735)\end{array}$ \\
\hline Public & $\begin{array}{l}4907 \\
(3353)\end{array}$ & $\begin{array}{l}1044 \\
(769)\end{array}$ & $\begin{array}{l}4204 \\
(3274)\end{array}$ & $\begin{array}{l}864 \\
(547)\end{array}$ & $\begin{array}{l}5453 \\
(4046)\end{array}$ & $\begin{array}{l}1175 \\
(754)\end{array}$ \\
\hline Private & $\begin{array}{l}3734 \\
(4123)\end{array}$ & $\begin{array}{l}794 \\
(571)\end{array}$ & $\begin{array}{l}2406 \\
(2018)\end{array}$ & $\begin{array}{l}726 \\
(547)\end{array}$ & $\begin{array}{l}3820 \\
(3954)\end{array}$ & $\begin{array}{l}1128 \\
(1032)\end{array}$ \\
\hline Self Employed & $\begin{array}{l}\text { NA } \\
(-)\end{array}$ & $\begin{array}{l}693 \\
(444)\end{array}$ & $\begin{array}{l}\text { NA } \\
(-)\end{array}$ & $\begin{array}{l}620 \\
(335)\end{array}$ & $\begin{array}{l}\text { NA } \\
(-)\end{array}$ & $\begin{array}{l}863 \\
(563)\end{array}$ \\
\hline Casual & $\begin{array}{l}1441 \\
(759)\end{array}$ & $\begin{array}{l}470 \\
(226)\end{array}$ & $\begin{array}{l}1646 \\
(897)\end{array}$ & $\begin{array}{l}515 \\
(273)\end{array}$ & $\begin{array}{l}1963 \\
(7885)\end{array}$ & $\begin{array}{l}592 \\
(309)\end{array}$ \\
\hline Unpaid Family Worker & $\begin{array}{l}\text { NA } \\
(-)\end{array}$ & $\begin{array}{l}853 \\
(767)\end{array}$ & $\begin{array}{l}\text { NA } \\
(-)\end{array}$ & $\begin{array}{l}579 \\
(270)\end{array}$ & $\begin{array}{l}\text { NA } \\
(-)\end{array}$ & $\begin{array}{l}806 \\
(462)\end{array}$ \\
\hline Not Employed & $\begin{array}{l}\text { NA } \\
(-)\end{array}$ & $\begin{array}{l}632 \\
(378)\end{array}$ & $\begin{array}{l}\text { NA } \\
(-)\end{array}$ & $\begin{array}{l}704 \\
(362)\end{array}$ & $\begin{array}{l}\text { NA } \\
(-)\end{array}$ & $\begin{array}{l}844 \\
(493)\end{array}$ \\
\hline
\end{tabular}

Notes: Standard deviation are in parentheses.

1. Data consists of men aged 18-40 living in urban India in the 1999 round of the National Sample Survey. MPCE is Monthly per capita expenditure. Wage and MPCE are expressed in Rupees. Wage and MPCE are deflated by Consumer Price Index-Industrial Worker (base 2001) to obtain real values. Weekly wage from NSS is multiplied by 4.33 to arrive at monthly wage. Wage data is not available (NA) for self-employed workers, and unemployed individuals, hence no average wage is reported for employment categories including them.

2. Paid Employment is comprised of salaried, self-employed and casual workers only.

3. Public sector employment consists of government jobs and semi-government jobs. Private sector employment consists of cooperative society, private limited company, and other units covered under Annual Survey of Industries, India. 
Table 5: Effect of ST Job Reservation on ST Employment Outcomes- All India

\begin{tabular}{|c|c|c|c|c|c|c|}
\hline & \multicolumn{2}{|c|}{$\underline{\operatorname{Pr}(\text { Employed })}$} & \multicolumn{2}{|c|}{$\underline{\operatorname{Pr}(\text { PaidEmp })}$} & \multicolumn{2}{|c|}{$\underline{\operatorname{Pr}(\text { Salaried } \mid \text { PaidEmp })}$} \\
\hline & $(1)$ & $(2)$ & (3) & (4) & (5) & $(6)$ \\
\hline ST Job Reservation & $\begin{array}{c}-0.003 \\
(0.003)\end{array}$ & $\begin{array}{c}-0.002 \\
(0.003)\end{array}$ & $\begin{array}{l}0.010 \\
(0.007)\end{array}$ & $\begin{array}{l}0.013^{*} \\
(0.006)\end{array}$ & $\begin{array}{c}-0.002 \\
(0.003)\end{array}$ & $\begin{array}{c}-0.003 \\
(0.003)\end{array}$ \\
\hline High Secondary & $\begin{array}{l}-0.079^{* * *} \\
(0.016)\end{array}$ & $\begin{array}{l}-0.078^{* * *} \\
(0.016)\end{array}$ & $\begin{array}{l}-0.066^{* * *} \\
(0.018)\end{array}$ & $\begin{array}{l}-0.064^{* * *} \\
(0.018)\end{array}$ & $\begin{array}{l}0.532^{* * *} \\
(0.023)\end{array}$ & $\begin{array}{l}0.531^{* * *} \\
(0.023)\end{array}$ \\
\hline Secondary & $\begin{array}{l}-0.101^{* * *} \\
(0.015)\end{array}$ & $\begin{array}{l}-0.100^{* * *} \\
(0.015)\end{array}$ & $\begin{array}{l}-0.115^{* * *} \\
(0.016)\end{array}$ & $\begin{array}{l}-0.113^{* * *} \\
(0.016)\end{array}$ & $\begin{array}{l}0.319^{* * *} \\
(0.026)\end{array}$ & $\begin{array}{l}0.318^{* * *} \\
(0.026)\end{array}$ \\
\hline Middle & $\begin{array}{l}-0.087^{* * *} \\
(0.016)\end{array}$ & $\begin{array}{l}-0.086^{* * *} \\
(0.016)\end{array}$ & $\begin{array}{l}-0.106^{* * *} \\
(0.019)\end{array}$ & $\begin{array}{l}-0.106^{* * *} \\
(0.019)\end{array}$ & $\begin{array}{l}0.128^{* * *} \\
(0.015)\end{array}$ & $\begin{array}{l}0.128^{* * *} \\
(0.015)\end{array}$ \\
\hline Primary & $\begin{array}{l}-0.051^{* * *} \\
(0.008)\end{array}$ & $\begin{array}{l}-0.052^{* * *} \\
(0.009)\end{array}$ & $\begin{array}{l}-0.055^{* * *} \\
(0.010)\end{array}$ & $\begin{array}{l}-0.056^{* * *} \\
(0.009)\end{array}$ & $\begin{array}{l}0.096^{* * *} \\
(0.021)\end{array}$ & $\begin{array}{l}0.096^{* * *} \\
(0.021)\end{array}$ \\
\hline Age & $\begin{array}{l}0.013^{* * *} \\
(0.003)\end{array}$ & $\begin{array}{l}0.013^{* * *} \\
(0.003)\end{array}$ & $\begin{array}{l}0.018^{* * *} \\
(0.003)\end{array}$ & $\begin{array}{l}0.018^{* * *} \\
(0.003)\end{array}$ & $\begin{array}{l}0.011^{* * *} \\
(0.003)\end{array}$ & $\begin{array}{l}0.011^{* * *} \\
(0.003)\end{array}$ \\
\hline Age Square & $\begin{array}{l}-0.000^{* * *} \\
(0.000)\end{array}$ & $\begin{array}{l}-0.000^{* * *} \\
(0.000)\end{array}$ & $\begin{array}{l}-0.000^{* * *} \\
(0.000)\end{array}$ & $\begin{array}{l}-0.000^{* * *} \\
(0.000)\end{array}$ & $\begin{array}{l}-0.000^{* * *} \\
(0.000)\end{array}$ & $\begin{array}{l}-0.000^{* * *} \\
(0.000)\end{array}$ \\
\hline Urban & $\begin{array}{l}-0.156^{* * *} \\
(0.012)\end{array}$ & $\begin{array}{l}-0.157^{* * *} \\
(0.012)\end{array}$ & $\begin{array}{l}-0.016 \\
(0.016)\end{array}$ & $\begin{array}{l}-0.016 \\
(0.016)\end{array}$ & $\begin{array}{l}0.246^{* * *} \\
(0.013)\end{array}$ & $\begin{array}{l}0.246^{* * *} \\
(0.014)\end{array}$ \\
\hline Male & $\begin{array}{l}0.409^{* * *} \\
(0.027)\end{array}$ & $\begin{array}{l}0.409^{* * *} \\
(0.027)\end{array}$ & $\begin{array}{l}0.487^{* * *} \\
(0.019)\end{array}$ & $\begin{array}{l}0.487^{* * *} \\
(0.019)\end{array}$ & $\begin{array}{l}0.023^{* *} \\
(0.009)\end{array}$ & $\begin{array}{l}0.023^{* *} \\
(0.009)\end{array}$ \\
\hline Married & $\begin{array}{l}-0.002 \\
(0.007)\end{array}$ & $\begin{array}{l}-0.002 \\
(0.007)\end{array}$ & $\begin{array}{l}0.069^{* * * *} \\
(0.011)\end{array}$ & $\begin{array}{l}0.070^{* * * *} \\
(0.011)\end{array}$ & $\begin{array}{l}-0.037^{* * *} \\
(0.008)\end{array}$ & $\begin{array}{l}-0.037^{* * *} \\
(0.008)\end{array}$ \\
\hline ST census population & $\begin{array}{l}-0.012 \\
(0.008)\end{array}$ & $\begin{array}{l}-0.008 \\
(0.009)\end{array}$ & $\begin{array}{l}-0.007 \\
(0.008)\end{array}$ & $\begin{array}{l}0.001 \\
(0.012)\end{array}$ & $\begin{array}{l}-0.001 \\
(0.010)\end{array}$ & $\begin{array}{l}-0.008 \\
(0.011)\end{array}$ \\
\hline ST current population & $\begin{array}{l}0.022^{* * *} \\
(0.008)\end{array}$ & $\begin{array}{l}0.015^{*} \\
(0.009)\end{array}$ & $\begin{array}{l}0.008 \\
(0.007)\end{array}$ & $\begin{array}{l}-0.005 \\
(0.013)\end{array}$ & $\begin{array}{l}-0.002 \\
(0.011)\end{array}$ & $\begin{array}{l}0.004 \\
(0.009)\end{array}$ \\
\hline $\operatorname{Lag}(1) \mathrm{SDP}$ & & $\begin{array}{l}-0.027^{* *} \\
(0.013)\end{array}$ & & $\begin{array}{l}-0.051^{*} \\
(0.028)\end{array}$ & & $\begin{array}{l}0.029^{* *} \\
(0.013)\end{array}$ \\
\hline Population density & & $\begin{array}{l}0.000^{* *} \\
(0.000)\end{array}$ & & $\begin{array}{l}0.001^{* * *} \\
(0.000)\end{array}$ & & $\begin{array}{l}-0.000 \\
(0.000)\end{array}$ \\
\hline$R^{2}$ & 0.30 & 0.31 & 0.28 & 0.28 & 0.22 & 0.22 \\
\hline Number of observations & 62511 & 62511 & 62511 & 62511 & 37277 & 37277 \\
\hline
\end{tabular}

Notes: Clustered standard errors by state and time are in parentheses. All the specifications also include state fixed effects, time fixed effects, and religion dummies. ST census population share is population shares measured by the most recent census, and ST current population share is the population share measured in current year.

* Significant at 10-percent level, ${ }^{* *}$ Significant at 5-percent level, and *** Significant at 1-percent level. 
Table 6: Effect of SC Job Reservation on SC Employment Outcomes- All India

\begin{tabular}{|c|c|c|c|c|c|c|}
\hline & \multicolumn{2}{|c|}{$\underline{\operatorname{Pr}(\text { Employed })}$} & \multicolumn{2}{|c|}{$\underline{\operatorname{Pr}(\text { PaidEmp })}$} & \multicolumn{2}{|c|}{$\underline{\operatorname{Pr}(\text { Salaried } \mid \text { PaidEmp })}$} \\
\hline & $(1)$ & $(2)$ & (3) & (4) & (5) & (6) \\
\hline SC Job Reservation & $\begin{array}{c}-0.004 \\
(0.003)\end{array}$ & $\begin{array}{c}-0.004 \\
(0.003)\end{array}$ & $\begin{array}{l}-0.005 \\
(0.003)\end{array}$ & $\begin{array}{c}-0.004 \\
(0.003)\end{array}$ & $\begin{array}{l}0.007^{* *} \\
(0.004)\end{array}$ & $\begin{array}{l}0.006^{* *} \\
(0.003)\end{array}$ \\
\hline High Secondary & $\begin{array}{l}-0.117^{* * *} \\
(0.018)\end{array}$ & $\begin{array}{l}-0.117^{* * *} \\
(0.018)\end{array}$ & $\begin{array}{l}-0.121^{* * *} \\
(0.016)\end{array}$ & $\begin{array}{l}-0.121^{* * *} \\
(0.016)\end{array}$ & $\begin{array}{l}0.462^{* * *} \\
(0.023)\end{array}$ & $\begin{array}{l}0.462^{* * *} \\
(0.023)\end{array}$ \\
\hline Secondary & $\begin{array}{l}-0.091^{* * *} \\
(0.018)\end{array}$ & $\begin{array}{l}-0.091^{* * *} \\
(0.018)\end{array}$ & $\begin{array}{l}-0.116^{* * *} \\
(0.017)\end{array}$ & $\begin{array}{l}-0.117^{* * *} \\
(0.017)\end{array}$ & $\begin{array}{l}0.244^{* * *} \\
(0.021)\end{array}$ & $\begin{array}{l}0.245^{* * *} \\
(0.021)\end{array}$ \\
\hline Middle & $\begin{array}{l}-0.065^{* * *} \\
(0.017)\end{array}$ & $\begin{array}{l}-0.065^{* * *} \\
(0.017)\end{array}$ & $\begin{array}{l}-0.089^{* * *} \\
(0.015)\end{array}$ & $\begin{array}{l}-0.089^{* * *} \\
(0.015)\end{array}$ & $\begin{array}{l}0.128^{* * *} \\
(0.012)\end{array}$ & $\begin{array}{l}0.128^{* * *} \\
(0.012)\end{array}$ \\
\hline Primary & $\begin{array}{l}-0.044^{* * *} \\
(0.009)\end{array}$ & $\begin{array}{l}-0.044^{* * *} \\
(0.009)\end{array}$ & $\begin{array}{l}-0.052^{* * *} \\
(0.009)\end{array}$ & $\begin{array}{l}-0.053^{* * *} \\
(0.009)\end{array}$ & $\begin{array}{l}0.111^{* * *} \\
(0.014)\end{array}$ & $\begin{array}{l}0.112^{* * *} \\
(0.014)\end{array}$ \\
\hline Age & $\begin{array}{l}0.022^{* * *} \\
(0.002)\end{array}$ & $\begin{array}{l}0.022^{* * *} \\
(0.002)\end{array}$ & $\begin{array}{l}0.026^{* * *} \\
(0.002)\end{array}$ & $\begin{array}{l}0.026^{* * *} \\
(0.002)\end{array}$ & $\begin{array}{l}0.009^{* * *} \\
(0.002)\end{array}$ & $\begin{array}{l}0.009^{* * *} \\
(0.002)\end{array}$ \\
\hline Age Square & $\begin{array}{l}-0.000^{* * *} \\
(0.000)\end{array}$ & $\begin{array}{l}-0.000^{* * *} \\
(0.000)\end{array}$ & $\begin{array}{l}-0.000^{* * *} \\
(0.000)\end{array}$ & $\begin{array}{l}-0.000^{* * *} \\
(0.000)\end{array}$ & $\begin{array}{l}-0.000^{* *} \\
(0.000)\end{array}$ & $\begin{array}{l}-0.000^{* *} \\
(0.000)\end{array}$ \\
\hline Urban & $\begin{array}{l}-0.106^{* * *} \\
(0.010)\end{array}$ & $\begin{array}{l}-0.106^{* * *} \\
(0.010)\end{array}$ & $\begin{array}{l}-0.062^{* * *} \\
(0.010)\end{array}$ & $\begin{array}{l}-0.062^{* * *} \\
(0.010)\end{array}$ & $\begin{array}{l}0.239^{* * *} \\
(0.011)\end{array}$ & $\begin{array}{l}0.239^{* * *} \\
(0.011)\end{array}$ \\
\hline Male & $\begin{array}{l}0.576^{* * *} \\
(0.024)\end{array}$ & $\begin{array}{l}0.576^{* * *} \\
(0.024)\end{array}$ & $\begin{array}{l}0.575^{* * *} \\
(0.020)\end{array}$ & $\begin{array}{l}0.575^{* * *} \\
(0.021)\end{array}$ & $\begin{array}{l}0.011 \\
(0.008)\end{array}$ & $\begin{array}{l}0.011 \\
(0.008)\end{array}$ \\
\hline Married & $\begin{array}{l}0.015^{* *} \\
(0.007)\end{array}$ & $\begin{array}{l}0.015^{* *} \\
(0.007)\end{array}$ & $\begin{array}{l}0.052^{* * * *} \\
(0.008)\end{array}$ & $\begin{array}{l}0.052^{* * *} \\
(0.008)\end{array}$ & $\begin{array}{l}-0.017^{* * *} \\
(0.006)\end{array}$ & $\begin{array}{l}-0.017^{* * *} \\
(0.006)\end{array}$ \\
\hline SC census population & $\begin{array}{l}-0.008^{* *} \\
(0.004)\end{array}$ & $\begin{array}{l}0.001 \\
(0.006)\end{array}$ & $\begin{array}{l}-0.008^{*} \\
(0.004)\end{array}$ & $\begin{array}{l}-0.000 \\
(0.005)\end{array}$ & $\begin{array}{l}-0.013^{* *} \\
(0.006)\end{array}$ & $\begin{array}{l}-0.014^{* *} \\
(0.007)\end{array}$ \\
\hline SC current population & $\begin{array}{l}0.001 \\
(0.003)\end{array}$ & $\begin{array}{l}0.001 \\
(0.003)\end{array}$ & $\begin{array}{l}0.002 \\
(0.003)\end{array}$ & $\begin{array}{l}0.003 \\
(0.003)\end{array}$ & $\begin{array}{l}0.010^{* *} \\
(0.004)\end{array}$ & $\begin{array}{l}0.009^{* *} \\
(0.004)\end{array}$ \\
\hline $\operatorname{Lag}(1) \mathrm{SDP}$ & & $\begin{array}{l}-0.006 \\
(0.008)\end{array}$ & & $\begin{array}{l}-0.018^{* *} \\
(0.008)\end{array}$ & & $\begin{array}{l}0.019^{*} \\
(0.010)\end{array}$ \\
\hline Population density & & $\begin{array}{l}0.000^{* * *} \\
(0.000)\end{array}$ & & $\begin{array}{l}0.000^{* * *} \\
(0.000)\end{array}$ & & $\begin{array}{l}-0.000^{* *} \\
(0.000)\end{array}$ \\
\hline$R^{2}$ & 0.41 & 0.41 & 0.38 & 0.38 & 0.20 & 0.20 \\
\hline Number of observations & 126189 & 126189 & 126189 & 126189 & 76241 & 76241 \\
\hline
\end{tabular}

Notes: Clustered standard errors by state and time are in parentheses. All the specifications also include state fixed effects, time fixed effects, and religion dummies. SC census population share is population shares measured by the most recent census, and SC current population share is the population share measured in current year.

* Significant at 10-percent level, ${ }^{* *}$ Significant at 5-percent level, and *** Significant at 1-percent level. 
Table 7: Effect of ST Job Reservation on ST Employment by Education- All India

\begin{tabular}{|c|c|c|c|c|c|c|}
\hline & \multicolumn{2}{|c|}{$\operatorname{Pr}($ Employed $)$} & \multicolumn{2}{|c|}{$\underline{\operatorname{Pr}(\text { PaidEmp })}$} & \multicolumn{2}{|c|}{$\underline{\operatorname{Pr}(\text { Salaried } \mid \text { PaidEmp })}$} \\
\hline & $(1)$ & $(2)$ & $(3)$ & $(4)$ & $(5)$ & $(6)$ \\
\hline ST Job Reservation & $\begin{array}{c}-0.002 \\
(0.003)\end{array}$ & $\begin{array}{c}-0.000 \\
(0.004)\end{array}$ & $\begin{array}{l}0.011 \\
(0.007)\end{array}$ & $\begin{array}{l}0.015^{*} \\
(0.008)\end{array}$ & $\begin{array}{c}-0.001 \\
(0.004)\end{array}$ & $\begin{array}{c}-0.002 \\
(0.004)\end{array}$ \\
\hline High Sec*ST Job Res & $\begin{array}{c}-0.003^{*} \\
(0.002)\end{array}$ & $\begin{array}{c}-0.003^{*} \\
(0.002)\end{array}$ & $\begin{array}{c}-0.001 \\
(0.002)\end{array}$ & $\begin{array}{c}-0.001 \\
(0.002)\end{array}$ & $\begin{array}{l}0.003 \\
(0.002)\end{array}$ & $\begin{array}{l}0.003 \\
(0.002)\end{array}$ \\
\hline Secondary*ST Job Res & $\begin{array}{l}0.000 \\
(0.002)\end{array}$ & $\begin{array}{c}-0.000 \\
(0.002)\end{array}$ & $\begin{array}{c}-0.002 \\
(0.002)\end{array}$ & $\begin{array}{c}-0.003 \\
(0.002)\end{array}$ & $\begin{array}{c}-0.004 \\
(0.004)\end{array}$ & $\begin{array}{c}-0.003 \\
(0.004)\end{array}$ \\
\hline Middle*ST Job Res & $\begin{array}{l}0.000 \\
(0.002)\end{array}$ & $\begin{array}{c}-0.000 \\
(0.002)\end{array}$ & $\begin{array}{c}-0.001 \\
(0.003)\end{array}$ & $\begin{array}{c}-0.002 \\
(0.003)\end{array}$ & $\begin{array}{l}0.001 \\
(0.002)\end{array}$ & $\begin{array}{l}0.002 \\
(0.002)\end{array}$ \\
\hline Primary*ST Job Res & $\begin{array}{c}-0.001 \\
(0.001)\end{array}$ & $\begin{array}{c}-0.002 \\
(0.001)\end{array}$ & $\begin{array}{c}-0.001 \\
(0.001)\end{array}$ & $\begin{array}{c}-0.002 \\
(0.001)\end{array}$ & $\begin{array}{c}-0.002 \\
(0.003)\end{array}$ & $\begin{array}{c}-0.002 \\
(0.003)\end{array}$ \\
\hline High Secondary & $\begin{array}{l}-0.042 \\
(0.029)\end{array}$ & $\begin{array}{l}-0.036 \\
(0.029)\end{array}$ & $\begin{array}{l}-0.057^{* *} \\
(0.027)\end{array}$ & $\begin{array}{l}-0.046^{*} \\
(0.027)\end{array}$ & $\begin{array}{l}0.497^{* * *} \\
(0.039)\end{array}$ & $\begin{array}{l}0.492^{* * *} \\
(0.041)\end{array}$ \\
\hline Secondary & $\begin{array}{l}-0.105^{* * *} \\
(0.029)\end{array}$ & $\begin{array}{l}-0.097^{* * *} \\
(0.030)\end{array}$ & $\begin{array}{l}-0.088^{* * *} \\
(0.032)\end{array}$ & $\begin{array}{l}-0.075^{* *} \\
(0.032)\end{array}$ & $\begin{array}{l}0.362^{* * *} \\
(0.050)\end{array}$ & $\begin{array}{l}0.355^{* * *} \\
(0.052)\end{array}$ \\
\hline Middle & $\begin{array}{l}-0.090^{* * *} \\
(0.034)\end{array}$ & $\begin{array}{l}-0.083^{* *} \\
(0.035)\end{array}$ & $\begin{array}{l}-0.097^{* *} \\
(0.040)\end{array}$ & $\begin{array}{l}-0.084^{* *} \\
(0.039)\end{array}$ & $\begin{array}{l}0.116^{* * *} \\
(0.027)\end{array}$ & $\begin{array}{l}0.109^{* * *} \\
(0.028)\end{array}$ \\
\hline Primary & $\begin{array}{l}-0.032^{*} \\
(0.019)\end{array}$ & $\begin{array}{l}-0.028 \\
(0.019)\end{array}$ & $\begin{array}{l}-0.040^{* *} \\
(0.018)\end{array}$ & $\begin{array}{l}-0.033^{*} \\
(0.018)\end{array}$ & $\begin{array}{l}0.125^{* * *} \\
(0.042)\end{array}$ & $\begin{array}{l}0.120^{* * *} \\
(0.043)\end{array}$ \\
\hline ST census population & $\begin{array}{l}-0.013 \\
(0.008)\end{array}$ & $\begin{array}{l}-0.008 \\
(0.009)\end{array}$ & $\begin{array}{l}-0.007 \\
(0.008)\end{array}$ & $\begin{array}{l}0.001 \\
(0.013)\end{array}$ & $\begin{array}{l}-0.001 \\
(0.010)\end{array}$ & $\begin{array}{l}-0.007 \\
(0.011)\end{array}$ \\
\hline ST current population & $\begin{array}{l}0.022^{* * *} \\
(0.008)\end{array}$ & $\begin{array}{l}0.014 \\
(0.009)\end{array}$ & $\begin{array}{l}0.007 \\
(0.007)\end{array}$ & $\begin{array}{l}-0.007 \\
(0.014)\end{array}$ & $\begin{array}{c}-0.003 \\
(0.011)\end{array}$ & $\begin{array}{l}0.004 \\
(0.010)\end{array}$ \\
\hline Other controls & $\mathrm{NO}$ & YES & NO & YES & $\mathrm{NO}$ & YES \\
\hline$R^{2}$ & 0.30 & 0.30 & 0.28 & 0.28 & 0.22 & 0.22 \\
\hline Number of observations & 62511 & 62511 & 62511 & 62511 & 37277 & 37277 \\
\hline
\end{tabular}

Notes: Clustered standard errors by state and time are in parentheses. All the specifications also include state fixed effects, timefixed effects, age, age square, married dummy, and religion dummies. Other controls consists of lag(1) SDP, and population density. ST census population share is population shares measured by the most recent census, and ST current population share is the population share measured in current year.

* Significant at 10-percent level,** Significant at 5-percent level, and *** Significant at 1-percent level. 
Table 8: Effect of SC Job Reservation on SC Employment by Education - All India

\begin{tabular}{|c|c|c|c|c|c|c|}
\hline & \multicolumn{2}{|c|}{$\underline{\operatorname{Pr}(\text { Employed })}$} & \multicolumn{2}{|c|}{$\underline{\operatorname{Pr}(\text { PaidEmp })}$} & \multicolumn{2}{|c|}{$\operatorname{Pr}($ Salaried $\mid$ PaidEmp $)$} \\
\hline & $(1)$ & $(2)$ & (3) & $(4)$ & (5) & (6) \\
\hline SC Job Reservation & $\begin{array}{l}-0.007^{* *} \\
(0.003)\end{array}$ & $\begin{array}{l}-0.007^{* *} \\
(0.003)\end{array}$ & $\begin{array}{l}-0.007^{*} \\
(0.004)\end{array}$ & $\begin{array}{l}-0.006^{*} \\
(0.004)\end{array}$ & $\begin{array}{l}0.010^{* *} \\
(0.004)\end{array}$ & $\begin{array}{l}0.009^{* *} \\
(0.004)\end{array}$ \\
\hline High Sec*SC Job Res & $\begin{array}{l}0.007^{* *} \\
(0.003)\end{array}$ & $\begin{array}{c}0.007^{* *} \\
(0.003)\end{array}$ & $\begin{array}{l}0.004 \\
(0.003)\end{array}$ & $\begin{array}{l}0.004 \\
(0.003)\end{array}$ & $\begin{array}{l}-0.008^{* * *} \\
(0.003)\end{array}$ & $\begin{array}{l}-0.008^{* * *} \\
(0.003)\end{array}$ \\
\hline Secondary*SC Job Res & $\begin{array}{l}0.005^{* *} \\
(0.002)\end{array}$ & $\begin{array}{c}0.005^{* *} \\
(0.002)\end{array}$ & $\begin{array}{l}0.004 \\
(0.003)\end{array}$ & $\begin{array}{l}0.003 \\
(0.002)\end{array}$ & $\begin{array}{l}-0.007^{* *} \\
(0.003)\end{array}$ & $\begin{array}{l}-0.007^{* *} \\
(0.003)\end{array}$ \\
\hline Middle*SC Job Res & $\begin{array}{l}0.004^{* *} \\
(0.002)\end{array}$ & $\begin{array}{l}0.004^{* *} \\
(0.002)\end{array}$ & $\begin{array}{l}0.002 \\
(0.002)\end{array}$ & $\begin{array}{l}0.002 \\
(0.002)\end{array}$ & $\begin{array}{c}-0.003 \\
(0.002)\end{array}$ & $\begin{array}{l}-0.003 \\
(0.002)\end{array}$ \\
\hline Primary*SC Job Res & $\begin{array}{l}0.003^{* *} \\
(0.002)\end{array}$ & $\begin{array}{l}0.003^{* *} \\
(0.002)\end{array}$ & $\begin{array}{l}0.002 \\
(0.002)\end{array}$ & $\begin{array}{l}0.002 \\
(0.001)\end{array}$ & $\begin{array}{l}-0.003 \\
(0.002)\end{array}$ & $\begin{array}{l}-0.003 \\
(0.002)\end{array}$ \\
\hline High Secondary & $\begin{array}{l}-0.230^{* * *} \\
(0.052)\end{array}$ & $\begin{array}{l}-0.230^{* * *} \\
(0.052)\end{array}$ & $\begin{array}{l}-0.190^{* * *} \\
(0.048)\end{array}$ & $\begin{array}{l}-0.190^{* * *} \\
(0.046)\end{array}$ & $\begin{array}{l}0.603^{* * *} \\
(0.044)\end{array}$ & $\begin{array}{l}0.603^{* * *} \\
(0.044)\end{array}$ \\
\hline Secondary & $\begin{array}{l}-0.178^{* * *} \\
(0.046)\end{array}$ & $\begin{array}{l}-0.178^{* * *} \\
(0.045)\end{array}$ & $\begin{array}{l}-0.177^{* * *} \\
(0.044)\end{array}$ & $\begin{array}{l}-0.177^{* * *} \\
(0.042)\end{array}$ & $\begin{array}{l}0.358^{* * *} \\
(0.041)\end{array}$ & $\begin{array}{l}0.357^{* * *} \\
(0.042)\end{array}$ \\
\hline Middle & $\begin{array}{l}-0.134^{* * *} \\
(0.035)\end{array}$ & $\begin{array}{l}-0.135^{* * *} \\
(0.034)\end{array}$ & $\begin{array}{l}-0.115^{* * *} \\
(0.035)\end{array}$ & $\begin{array}{l}-0.120^{* * *} \\
(0.033)\end{array}$ & $\begin{array}{l}0.175^{* * *} \\
(0.038)\end{array}$ & $\begin{array}{l}0.179^{* * *} \\
(0.038)\end{array}$ \\
\hline Primary & $\begin{array}{l}-0.100^{* * *} \\
(0.029)\end{array}$ & $\begin{array}{l}-0.100^{* * *} \\
(0.028)\end{array}$ & $\begin{array}{l}-0.082^{* * *} \\
(0.028)\end{array}$ & $\begin{array}{l}-0.084^{* * *} \\
(0.027)\end{array}$ & $\begin{array}{l}0.167^{* * *} \\
(0.037)\end{array}$ & $\begin{array}{l}0.169^{* * *} \\
(0.037)\end{array}$ \\
\hline $\mathrm{SC}$ census population & $\begin{array}{l}-0.007 \\
(0.004)\end{array}$ & $\begin{array}{l}0.003 \\
(0.006)\end{array}$ & $\begin{array}{l}-0.007 \\
(0.004)\end{array}$ & $\begin{array}{l}0.001 \\
(0.006)\end{array}$ & $\begin{array}{l}-0.014^{* * *} \\
(0.005)\end{array}$ & $\begin{array}{l}-0.016^{* *} \\
(0.006)\end{array}$ \\
\hline SC current population & $\begin{array}{l}-0.000 \\
(0.003)\end{array}$ & $\begin{array}{l}-0.000 \\
(0.003)\end{array}$ & $\begin{array}{l}0.002 \\
(0.003)\end{array}$ & $\begin{array}{l}0.002 \\
(0.003)\end{array}$ & $\begin{array}{l}0.011^{* * *} \\
(0.004)\end{array}$ & $\begin{array}{l}0.010^{* * *} \\
(0.004)\end{array}$ \\
\hline Other controls & NO & YES & NO & YES & NO & YES \\
\hline$R^{2}$ & 0.41 & 0.41 & 0.38 & 0.38 & 0.20 & 0.20 \\
\hline Number of observations & 126189 & 126189 & 126189 & 126189 & 76241 & 76241 \\
\hline
\end{tabular}

Notes: Clustered standard errors by state and time are in parentheses. All the specifications also include state fixed effects, timefixed effects, age, age square, married dummy, and religion dummies. Other controls consists of lag(1) SDP, and population density. $\mathrm{SC}$ census population share is population shares measured by the most recent census, and SC current population share is the population share measured in current year.

* Significant at 10-percent level,** Significant at 5-percent level, and *** Significant at 1-percent level. 
Table 9: Effect of ST Job Reservation on ST Employment by Sector and Gender

\section{$\operatorname{Pr}($ Employed $) \quad \operatorname{Pr}($ PaidEmp $) \quad \operatorname{Pr}($ Salaried $\mid$ PaidEmp $)$}

$(1)$

$\begin{array}{cc}-0.004 & -0.007 \\ (0.005) & (0.006) \\ 0.005 & 0.013 \\ (0.005) & (0.009) \\ -0.004 & 0.017^{* *} \\ (0.007) & (0.007) \\ 0.004 & 0.031^{* *} \\ (0.009) & (0.015)\end{array}$

0.006

Estimated effect of ST Job Reservation

ST Job Reservation

ST Job Res*Male*Rural

ST Job Res*Female*Urban

ST Job Res*Female*Rural

ํㅣ Hypothesis Tests

$H_{0}:$ Male Urban Effect=Female Urban Effect

$[0.596]$

$[0.024]$

$[0.365]$

$[0.186]$

$(0.008)$

$-0.012$

$0.009)$

0.004

$(0.004)$

$-0.006$

$(0.008)$

$H_{0}$ :Male Urban Effect=Male Rural Effect

$H_{0}$ :Male Rural Effect=Female Rural Effect

$[0.885]$

$[0.226]$

$H_{0}$ :Female Urban Effect=Female Rural Effect
[0.169]
$[0.317]$

Notes: Each row-column reports the coefficient and associated standard error from a separate regression. Clustered standard errors by state and timeare in parentheses and p-values are in brackets. All the specifications also include state fixed effects, time fixed effects, age, age square, married dummy, sector dummy, gender dummy, education dummies, religion dummies, ST census population share, ST current population share, lag(1) SDP, and population density, all of which are allowed to vary by gender dummy and sector dummy.

ST census population share is population shares measured by the most recent census.

ST current population share is the population share measured in current year.

* Significant at 10-percent level,** Significant at 5-percent level, and *** Significant at 1-percent level. 
Table 10: Effect of SC Job Reservation on SC Employment by Sector and Gender

\section{$\operatorname{Pr}($ Employed $) \quad \operatorname{Pr}($ PaidEmp $) \quad \operatorname{Pr}($ Salaried $\mid$ PaidEmp $)$}

(1)

$\begin{array}{cc}-0.007^{* * *} & -0.006^{* *} \\ (0.002) & (0.003) \\ 0.008^{* * *} & 0.008^{* * *} \\ (0.003) & (0.003) \\ 0.001 & 0.001 \\ (0.005) & (0.004) \\ -0.004 & -0.003 \\ (0.006) & (0.005)\end{array}$

$(2)$

Estimated effect of SC Job Reservation

SC Job Reservation

SC Job Res*Male*Rural

SC Job Res*Female*Urban

SC Job Res*Female*Rural

\section{Hypothesis Tests}

$H_{0}:$ Male Urban Effect=Female Urban Effect

$H_{0}:$ Male Urban Effect=Male Rural Effect

$[0.006]$

$H_{0}:$ Male Rural Effect=Female Rural Effect

$H_{0}:$ Female Urban Effect=Female Rural Effect

[0.090]

$[0.246]$

[0.000]

Notes: Each row-column reports the coefficient and associated standard error from a separate regression. Clustered standard errors by state and timeare in parentheses and p-values are in brackets. All the specifications also include state fixed effects, time fixed effects, age, age square, married dummy, sector dummy, gender dummy, education dummies, religion dummies, SC census population share, SC current population share, lag(1) SDP, and population density, all of which are allowed to vary by gender dummy and sector dummy.

$\mathrm{SC}$ census population share is population shares measured by the most recent census.

$\mathrm{SC}$ current population share is the population share measured in current year.

* Significant at 10-percent level,** Significant at 5-percent level, and *** Significant at 1-percent level. 
Table 11: Effect of ST Job Reservation on Wages of Salaried Jobs for Men in Urban Sector, State-Year-Level Data

\begin{tabular}{lcc}
\hline \hline Dependent Variable: & Mean of dependent variable & Coefficient for ST Job Reservation \\
\hline Log(Average $)$ & 6.56 & 0.025 \\
& $(0.37)$ & $(0.044)$ \\
$\log \left(90^{\text {th }}\right.$ Percentile $)$ & 7.10 & -0.016 \\
& $(0.43)$ & $(0.041)$ \\
$\log \left(75^{\text {th }}\right.$ Percentile $)$ & 6.79 & -0.000 \\
& $(0.41)$ & $(0.046)$ \\
$\log ($ Median $)$ & 6.46 & 0.019 \\
& $(0.40)$ & $0.043)$ \\
$\log \left(25^{\text {th }}\right.$ Percentile $)$ & 6.00 & 0.102 \\
& $(0.48)$ & $(0.062)$ \\
$\log \left(10^{\text {th }}\right.$ Percentile $)$ & 5.63 & 0.052 \\
& $(0.52)$ & $(0.066)$ \\
Number of observations & 63 & 63 \\
\end{tabular}

Notes: Each row-column reports the coefficient and associated standard error from a separate regression. Wages at the state-year level computed using men salaried workers age 18-40 living in urban India are used. Robust standard errors are in parentheses. All the specifications also include state fixed effects, time fixed effects, ST census population share, ST current population share, lag(1) SDP, and population density.

* Significant at 10-percent level, ${ }^{* *}$ Significant at 5-percent level, and *** Significant at 1-percent level. 
Table 12: Effect of SC Job Reservation on Wages of Salaried Jobs for Men in Urban Sector, State-Year-Level Data

\begin{tabular}{lcc}
\hline \hline Dependent Variable: & Mean of dependent variable & Coefficient for SC Job Reservation \\
\hline Log $($ Average $)$ & 6.41 & -0.022 \\
& $(0.31)$ & $(0.018)$ \\
$\log \left(90^{\text {th }}\right.$ Percentile $)$ & 6.94 & -0.006 \\
& $(0.37)$ & $(0.013)$ \\
$\log \left(75^{\text {th }}\right.$ Percentile $)$ & 6.64 & -0.002 \\
& $(0.32)$ & $(0.010)$ \\
$\log ($ Median $)$ & 6.29 & -0.011 \\
& $(0.30)$ & $(0.016)$ \\
$\log \left(25^{\text {th }}\right.$ Percentile $)$ & 5.84 & -0.021 \\
& $(0.29)$ & $(0.017)$ \\
Log $\left(10^{\text {th }}\right.$ Percentile $)$ & 5.35 & -0.060 \\
& $(0.55)$ & $(0.040)$ \\
Number of observations & 64 & 64 \\
\hline \hline Notes: Each row-column reports the coefficient and associated standard error from a separate regression. Wages at the \\
state-year level computed using men salaried workers age 18-40 living in urban India are used. Robust standard errors are \\
in parentheses. All the specifications also include state fixed effects, time fixed effects, SC census population share, \\
SC current population share, lag(1) SDP, and population density.
\end{tabular}


Table 13: Effect of ST Job Reservation on MPCE for Men Urban Sector, State-Year-Level Data

\begin{tabular}{|c|c|c|c|c|}
\hline \multirow[t]{2}{*}{ Dependent Variable: } & \multicolumn{2}{|c|}{ Mean of dependent variable } & \multicolumn{2}{|c|}{ Coefficient for ST Job Reservation } \\
\hline & Men (High Educated) & Men (Low Educated) & Men (High Educated) & Men (Low Educated) \\
\hline \multirow[t]{2}{*}{$\log ($ Average $)$} & 6.97 & 6.43 & -0.044 & 0.024 \\
\hline & $(0.33)$ & $(0.23)$ & $(0.046)$ & $(0.020)$ \\
\hline \multirow[t]{2}{*}{$\log \left(90^{\text {th }}\right.$ Percentile $)$} & 7.48 & 6.93 & -0.138 & 0.036 \\
\hline & $(0.48)$ & $(0.28)$ & $(0.082)$ & $(0.030)$ \\
\hline \multirow[t]{2}{*}{$\log \left(75^{\text {th }}\right.$ Percentile $)$} & 7.17 & 6.58 & 0.009 & 0.026 \\
\hline & $(0.41)$ & $(0.26)$ & $(0.057)$ & $(0.028)$ \\
\hline \multirow[t]{2}{*}{$\log ($ Median $)$} & 6.76 & 6.27 & 0.044 & 0.006 \\
\hline & $(0.38)$ & $(0.28)$ & $(0.046)$ & $(0.033)$ \\
\hline \multirow[t]{2}{*}{$\log \left(25^{\text {th }}\right.$ Percentile $)$} & 6.44 & 5.99 & -0.012 & 0.011 \\
\hline & $(0.39)$ & $(0.28)$ & $(0.048)$ & $(0.028)$ \\
\hline \multirow[t]{2}{*}{$\log \left(10^{\text {th }}\right.$ Percentile $)$} & 6.27 & 5.73 & 0.039 & -0.014 \\
\hline & $(0.45)$ & $(0.33)$ & $(0.057)$ & $(0.032)$ \\
\hline Number of observations & 59 & 63 & 59 & 63 \\
\hline
\end{tabular}

Notes: Monthly per capita expenditure (MPCE) at the state-year level computed using men age 18-40 living in urban India are used.

Each row-column reports the coefficient and associated standard error from a separate regression. Robust standard errors are in parentheses.

All the specifications also include state fixed effects, time fixed effects, ST census population share, ST current population share, lag(1) SDP,

and population density. High Educated implies an individuals with secondary and above education while Low Educated implies individuals

with middle and below education.

* Significant at 10-percent level, ${ }^{* *}$ Significant at 5-percent level, and *** Significant at 1-percent level. 
Table 14: Effect of SC Job Reservation on MPCE for Men Urban Sector, State-Year-Level Data

\begin{tabular}{|c|c|c|c|c|}
\hline \multirow[t]{2}{*}{ Dependent Variable: } & \multicolumn{2}{|c|}{ Mean of dependent variable } & \multicolumn{2}{|c|}{ Coefficient for SC Job Reservation } \\
\hline & Men (High Educated) & Men (Low Educated) & Men (High Educated) & Men (Low Educated) \\
\hline \multirow[t]{2}{*}{ Log $($ Average $)$} & 6.83 & 6.50 & -0.039 & 0.007 \\
\hline & $(0.59)$ & $(0.59)$ & $(0.098)$ & $(0.071)$ \\
\hline \multirow[t]{2}{*}{$\log \left(90^{\text {th }}\right.$ Percentile $)$} & 7.38 & 6.84 & -0.051 & -0.004 \\
\hline & $(0.76)$ & $(0.16)$ & $(0.130)$ & $(0.018)$ \\
\hline \multirow[t]{2}{*}{$\log \left(75^{\text {th }}\right.$ Percentile $)$} & 6.98 & 6.49 & -0.000 & $0.027^{* *}$ \\
\hline & $(0.32)$ & $(0.14)$ & $(0.048)$ & $(0.013)$ \\
\hline \multirow[t]{2}{*}{$\log ($ Median $)$} & 6.59 & 6.18 & 0.009 & $0.033^{* * *}$ \\
\hline & $(0.26)$ & $(0.14)$ & $(0.036)$ & $(0.010)$ \\
\hline \multirow{2}{*}{$\log \left(25^{\text {th }}\right.$ Percentile $)$} & 6.28 & 5.91 & 0.029 & $0.036^{* * *}$ \\
\hline & $(0.26)$ & $(0.15)$ & $(0.029)$ & $(0.012)$ \\
\hline \multirow[t]{2}{*}{$\log \left(10^{\text {th }}\right.$ Percentile $)$} & 5.99 & 5.67 & $0.098^{*}$ & $0.026^{* *}$ \\
\hline & $(0.34)$ & $(0.16)$ & $(0.049)$ & $(0.013)$ \\
\hline Number of observations & 63 & 64 & 63 & 64 \\
\hline
\end{tabular}

Notes: Monthly per capita expenditure (MPCE) at the state-year level computed using men age 18-40 living in urban India are used.

Each row-column reports the coefficient and associated standard error from a separate regression. Robust standard errors are in parentheses.

All the specifications also include state fixed effects, time fixed effects, SC census population share, SC current population share, lag(1) SDP,

and population density. High Educated implies an individuals with secondary and above education while Low Educated implies individuals

with middle and below education.

* Significant at 10-percent level, ${ }^{* *}$ Significant at 5-percent level, and *** Significant at 1-percent level. 
Table 15: Instrumental Variable Estimates of the Effects of ST and SC Job Reservations

\section{$\underline{\operatorname{Pr}(\text { Employed })} \quad \operatorname{Pr}($ PaidEmp $) \quad \operatorname{Pr}($ Salaried $\mid$ PaidEmp $)$}

PANEL A: Effect of ST Job Reservation on ST Employment First Stage: (Endogenous Regressor, ST Job Reservation is the dependent variable)

ST Political Reservation (Identifying Instrument)

$\begin{array}{ccc}1.024^{* * *} & 1.024^{* * *} & 0.964^{* * *} \\ (0.027) & (0.027) & (0.037) \\ {[38.06]} & {[38.06]} & {[26.25]} \\ & & \\ -0.022 & 0.081 & 0.020 \\ (0.022) & (0.060) & (0.033)\end{array}$

Second Stage

ST Job Reservation (2SLS estimate)

Employment the dependent variable)

SC Political Reservation (Identifying Instrument)

$\begin{array}{ccc}0.183^{* * *} & 0.183^{* * *} & 0.254^{* * *} \\ (0.007) & (0.007) & (0.010) \\ {[26.19]} & {[26.19]} & {[24.58]} \\ & & \\ 0.019 & 0.002 & 0.044 \\ (0.046) & (0.034) & (0.039)\end{array}$

Second Stage

SC Job Reservation (2SLS estimate)

$(0.046)$

$(0.039)$

Notes: Each row-column reports the coefficient and associated standard error from a separate regression. Clustered standard errors by state and time are in parentheses. The figure in brackets is the associated t-statistic. All the specifications also include state fixed effects, time fixed effects, age, age square, gender dummy, sector dummy, education dummies, religion dummies, lag(1) SDP, and population density. $\mathrm{SC} / \mathrm{ST}$ census population share is population shares measured by the most recent census.

$\mathrm{SC} / \mathrm{ST}$ current population share is the population share measured in current year.

* Significant at 10-percent level, ${ }^{* *}$ Significant at 5-percent level, and ${ }^{* * *}$ Significant at 1-percent level. 


\section{Appendix A}

\section{Data Sources and Construction of Variables}

This paper builds on a wide variety of data sources. The data source used in this paper covers sixteen main Indian states from the period 1983-1999 unless mentioned otherwise. These states are Andhra Pradesh, Assam, Bihar, Gujarat, Haryana, JammuKashmir, Karnataka, Kerala, Madhya Pradesh, Maharashtra, Orissa, Punjab, Rajasthan, Tamil Nadu, Uttar Pradesh and West Bengal. The outcome variables and individual level control variables comes from the National Sample Survey (NSS) rounds conducted in 1983, 1987, 1993 and 1999. These are large quinquennial surveys that covered the Employment and Unemployment rounds. The Employment and Unemployment round of NSS is the only survey that collects information on individual's earning and labor market characteristics for the entire India. Each survey collects information on approximately 120,000 households and over half a million individuals. The policy variables comes from the Annual Scheduled Caste and Scheduled Tribe Commissioner's Report (1955-2000). NSS is an individual-level data while my policy variables are at state-time level. These policy variables are merged into the NSS individual-level data by state and year.

\section{Outcome Variables}

\section{Employment}

The employment outcomes are constructed using NSS Employment and Unemployment rounds. From the NSS, I extract the following sample: individuals who are currently aged 18-40, living in one of the 16 major Indian states, and not currently attending school. The first data restriction is because only SCs and STs in this age range are eligible to apply for the reserved public sector jobs. The second restriction is because the job reservation variables I have cover these states over the 1983-1999 time period consistently; at any rate, it should have minimal impact since these 16 states account for over 95 percent of the Indian population. This paper uses three employment outcomes for SCs and STs, defined as follows:

(a) Probability of being employed: The NSS counts an individual as employed if he/she reports to be self-employed, unpaid family worker, worked as regular salaried/wage employee or worked as casual wage labor. The outcome variable denoted as $\operatorname{Pr}($ Employed) 
takes the value 1 if employed, 0 otherwise.

(b) Probability of being in Paid Employment: Formal definition of labor market considers self-employed, salaried and casual workers as the paid employment category. The outcome variable denoted as $\operatorname{Pr}$ (Paid Employed) takes the value 1 if paid employed, 0 otherwise.

(c) Probability of being a salaried worker conditional on being in paid employment: The outcome variable denoted as $\operatorname{Pr}$ (Salaried|Paid Employed) takes the value 1 if an individual reports to have worked as regular salaried/wage employee conditional on being in paid employment category, 0 otherwise.

\section{Wage Percentiles}

This paper looks at the wage distribution for SCs and STs as an outcome at state level. The outcome variable denoted as $W_{\text {st }}$ stands for log wage at the mean and the following percentiles : $10^{t h}, 25^{t h}, 50^{t h}, 75^{t h}, 90^{t h}$. For this analysis, we focus on log monthly wages for full time workers, defined as those who worked at least five days per week according to $\mathrm{NSS}^{12}$. An individual who worked for more than one hour but less than four hours per day is considered as working for half a day according to the NSS. Monthly wage is computed by multiplying weekly wage of the individual by 4.33. Wages or earnings refer to the wage/salaried income received for the wage/salaried work done during the reference week. Wages are expressed in real terms and deflated using Consumer Price Index for Industrial Workers (CPI-IW) with 2001 as the base year. CPI-IW are drawn from the Indian Labor Handbook, the Indian Labor Journal and the Reserve Bank of India Report on Currency and Finance. The sample is restricted to urban males aged 18-40, who are reported as full time worker in regular salaried employment and do not attend any educational institution. Additionally, the sample is restricted to individuals earning non-negative wage from their primary activity. The unit of analysis is the state-time cell. I can only do this analysis for urban males because for them, there are reasonable number of observations per cell. There are much fewer salaried workers among women and rural residents. The sample of data can be considered to be of representative Indian workers with reasonable laborforce attachment.

\section{Average Monthly Per Capita Expenditure (MPCE)}

This paper looks at the distribution of household monthly per capita consumption expenditure for SCs and STs as an outcome at the state level. The outcome variable denoted as $M P C E_{s t}$ stands for log MPCE at the mean and the following percentiles : $10^{t h}, 25^{t h}, 50^{t h}$,

\footnotetext{
${ }^{12}$ Wage/salaried employees working less than five days per week account for almost 8-percent of all wage/salaried workers.
} 
$75^{t h}, 90^{t h}$. MPCE is expressed in real terms and deflated using Consumer Price Index for Industrial Workers (CPI-IW) with 2001 as the base year. CPI-IW are drawn from the Indian Labor Handbook, the Indian Labor Journal and the Reserve Bank of India Report on Currency and Finance. The sample is restricted to households with non-negative monthly per capita expenditure. The unit of analysis is the state-time cell.

\section{Policy and Control Variables}

\section{Employment quota}

This paper uses the Scheduled Caste and Scheduled Tribe Annual Commissioner's Report (1955-2000) for the employment quota variables for SCs and STs. The institutional details for the Job Reservation policy also comes from this report. This is a state level data available for the period 1955-1999. The employment quota variables are "Percentage of Jobs reserved for SC" and "Percentage of Jobs reserved for ST" and is denoted as "SC Job Reservation" and "ST Job Reservation".

-Percentage of Jobs reserved for SC(ST): defined as total number of jobs reserved for $\mathrm{SC}(\mathrm{ST})$ in public sector divided by total number of new jobs advertised in the state in a specific year.

\section{Population data}

This paper uses Census of India, Registrar General data from 1981-2001. The data series has been interpolated for inter-censal years. I use two main control variables. First, "SC (ST) census population share" which is defined as the percentage of SC (ST) population share reported by the Census of India. This variable is updated each time a new census estimate arrives for a state. The second control variable is, "SC (ST) current population share" which is the interpolated SC (ST) population share from the census as measured in the current year. Population density is computed as the ratio of interpolated total population data from the census as measured when reservation was determined in the state divided by total land area of the state, as reported in the Census Atlas, India. This variable is also updated according to the two conditions described above.

-SC (or ST) Census population share: defined as population count of SC (or ST) in a state divided by total population count in that state at the time of census.

-SC (or ST) Current population share: defined as population count of SC (or ST) in a state divided by total population count in that state in the current year. 
- Census population density: defined as interpolated total population count from the census as measured when reservation was determined divided by total land area in a state.

\section{Individual Characteristics from the NSS}

The individual level controls for this paper is extracted from the NSS. They are an individual's age, gender, marital status, religion and education. This paper constructs four

dummy variables for educational attainment (primary school, middle school, secondary school, and upper secondary school or higher; the omitted group is uneducated). I construct seven religion dummies based on the NSS (Islam, Christianity, Sikhism, Jainism, Buddhism, and Zoroastrianism; the omitted group is Hinduism).

\section{State Domestic Product}

State domestic product is the log of real per capita state income. The data source is: Domestic Product of States of India from 1983 to 2000 prepared by Economic and Political Weekly Research Foundation. 


\section{Appendix B}

Table B-1: Additional Descriptive Statistics- All India

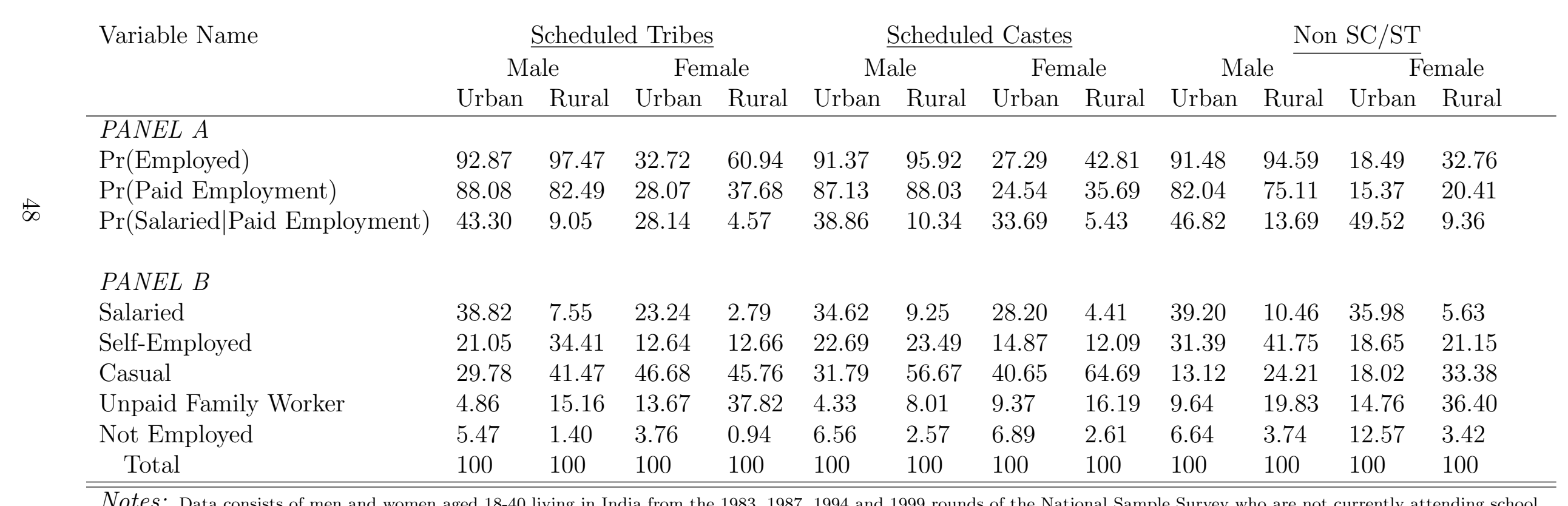

Notes: Data consists of men and women aged 18-40 living in India from the 1983, 1987, 1994 and 1999 rounds of the National Sample Survey who are not currently attending school. 


\section{Appendix C}

Table C-1: Effect of ST Job Reservation on Non SC/ST Employment Outcomes- All India

\begin{tabular}{|c|c|c|c|c|c|c|}
\hline & \multicolumn{2}{|c|}{$\operatorname{Pr}($ Employed $)$} & \multicolumn{2}{|c|}{$\operatorname{Pr}($ PaidEmp $)$} & \multicolumn{2}{|c|}{$\underline{\operatorname{Pr}(\text { Salaried } \mid \text { PaidEmp })}$} \\
\hline & $(1)$ & $(2)$ & $(3)$ & $(4)$ & $(5)$ & $(6)$ \\
\hline ST Job Reservation & $\begin{array}{c}-0.001 \\
(0.003)\end{array}$ & $\begin{array}{c}-0.001 \\
(0.003)\end{array}$ & $\begin{array}{l}0.005 \\
(0.003)\end{array}$ & $\begin{array}{l}0.004 \\
(0.003)\end{array}$ & $\begin{array}{l}-0.008^{* *} \\
(0.004)\end{array}$ & $\begin{array}{l}-0.008^{* *} \\
(0.003)\end{array}$ \\
\hline High Secondary & $\begin{array}{l}-0.064^{* * *} \\
(0.011)\end{array}$ & $\begin{array}{l}-0.064^{* * *} \\
(0.011)\end{array}$ & $\begin{array}{l}-0.039^{* * *} \\
(0.011)\end{array}$ & $\begin{array}{l}-0.039^{* * *} \\
(0.010)\end{array}$ & $\begin{array}{l}0.419^{* * *} \\
(0.017)\end{array}$ & $\begin{array}{l}0.419^{* * *} \\
(0.017)\end{array}$ \\
\hline Secondary & $\begin{array}{l}-0.092^{* * *} \\
(0.014)\end{array}$ & $\begin{array}{l}-0.092^{* * *} \\
(0.014)\end{array}$ & $\begin{array}{l}-0.099^{* * *} \\
(0.011)\end{array}$ & $\begin{array}{l}-0.100^{* * *} \\
(0.011)\end{array}$ & $\begin{array}{l}0.271^{\text {*** }} \\
(0.016)\end{array}$ & $\begin{array}{l}0.272^{* * *} \\
(0.016)\end{array}$ \\
\hline Middle & $\begin{array}{l}-0.081^{* * *} \\
(0.013)\end{array}$ & $\begin{array}{l}-0.081^{* * *} \\
(0.013)\end{array}$ & $\begin{array}{l}-0.093^{* * *} \\
(0.011)\end{array}$ & $\begin{array}{l}-0.093^{* * *} \\
(0.011)\end{array}$ & $\begin{array}{l}0.163^{\text {*** }} \\
(0.011)\end{array}$ & $\begin{array}{l}0.164^{* * *} \\
(0.012)\end{array}$ \\
\hline Primary & $\begin{array}{l}-0.060^{* * *} \\
(0.006)\end{array}$ & $\begin{array}{l}-0.059^{* * *} \\
(0.006)\end{array}$ & $\begin{array}{l}-0.054^{* * *} \\
(0.006)\end{array}$ & $\begin{array}{l}-0.054^{* * *} \\
(0.006)\end{array}$ & $\begin{array}{l}0.158^{* * *} \\
(0.016)\end{array}$ & $\begin{array}{l}0.158^{* * *} \\
(0.016)\end{array}$ \\
\hline Age & $\begin{array}{l}0.013^{* * *} \\
(0.001)\end{array}$ & $\begin{array}{l}0.013^{* * *} \\
(0.001)\end{array}$ & $\begin{array}{l}0.017^{* * *} \\
(0.002)\end{array}$ & $\begin{array}{l}0.017^{* * *} \\
(0.001)\end{array}$ & $\begin{array}{l}0.010^{* * *} \\
(0.002)\end{array}$ & $\begin{array}{l}0.010^{* * *} \\
(0.002)\end{array}$ \\
\hline Age Square & $\begin{array}{l}-0.000^{* * *} \\
(0.000)\end{array}$ & $\begin{array}{l}-0.000^{* * *} \\
(0.000)\end{array}$ & $\begin{array}{l}-0.000^{* * *} \\
(0.000)\end{array}$ & $\begin{array}{l}-0.000^{* * *} \\
(0.000)\end{array}$ & $\begin{array}{l}-0.000^{* * *} \\
(0.000)\end{array}$ & $\begin{array}{l}-0.000^{* * *} \\
(0.000)\end{array}$ \\
\hline ST census population & $\begin{array}{l}-0.002 \\
(0.004)\end{array}$ & $\begin{array}{l}0.004 \\
(0.004)\end{array}$ & $\begin{array}{l}-0.009 \\
(0.005)\end{array}$ & $\begin{array}{l}-0.008 \\
(0.006)\end{array}$ & $\begin{array}{l}-0.003 \\
(0.005)\end{array}$ & $\begin{array}{l}-0.007 \\
(0.006)\end{array}$ \\
\hline ST current population & $\begin{array}{l}0.002 \\
(0.004)\end{array}$ & $\begin{array}{l}0.002 \\
(0.005)\end{array}$ & $\begin{array}{l}0.006 \\
(0.006)\end{array}$ & $\begin{array}{l}0.004 \\
(0.006)\end{array}$ & $\begin{array}{l}0.009 \\
(0.006)\end{array}$ & $\begin{array}{l}0.012^{*} \\
(0.006)\end{array}$ \\
\hline $\operatorname{Lag}(1)$ SDP & & $\begin{array}{l}-0.001 \\
(0.007)\end{array}$ & & $\begin{array}{l}-0.011 \\
(0.010)\end{array}$ & & $\begin{array}{l}0.014^{*} \\
(0.007)\end{array}$ \\
\hline Population density & & $\begin{array}{l}-0.000 \\
(0.000)\end{array}$ & & $\begin{array}{l}0.000^{* * *} \\
(0.000)\end{array}$ & & $\begin{array}{l}-0.000 \\
(0.000)\end{array}$ \\
\hline$R^{2}$ & 0.50 & 0.50 & 0.40 & 0.40 & 0.25 & 0.25 \\
\hline Number of observations & 613699 & 613699 & 613699 & 613699 & 297597 & 297597 \\
\hline
\end{tabular}

Notes: Clustered standard errors by state and time are in parentheses. All the specifications also include state fixed effects, time fixed effects, sector dummy, gender dummy, age, age square, married dummy, and religion dummies. $\mathrm{SC} / \mathrm{ST}$ census population share is population shares measured by the most recent census.

$\mathrm{SC} / \mathrm{ST}$ current population share is the population share measured in current year.

* Significant at 10-percent level, ${ }^{* *}$ Significant at 5-percent level, and *** Significant at 1-percent level. 
Table C-2: Effect of SC Job Reservation on Non SC/ST Employment Outcomes- All India

\begin{tabular}{|c|c|c|c|c|c|c|}
\hline & \multicolumn{2}{|c|}{$\underline{\operatorname{Pr}(\text { Employed })}$} & \multicolumn{2}{|c|}{$\underline{\operatorname{Pr}(\text { PaidEmp })}$} & \multicolumn{2}{|c|}{ Pr $($ Salaried $\mid$ PaidEmp $)$} \\
\hline & $(1)$ & $(2)$ & (3) & (4) & (5) & (6) \\
\hline SC Job Reservation & $\begin{array}{c}-0.001 \\
(0.002)\end{array}$ & $\begin{array}{l}-0.001 \\
(0.002)\end{array}$ & $\begin{array}{l}-0.003 \\
(0.004)\end{array}$ & $\begin{array}{l}-0.002 \\
(0.004)\end{array}$ & $\begin{array}{l}0.005 \\
(0.004)\end{array}$ & $\begin{array}{l}0.005 \\
(0.004)\end{array}$ \\
\hline High Secondary & $\begin{array}{l}-0.064^{* * *} \\
(0.011)\end{array}$ & $\begin{array}{l}-0.064^{* * *} \\
(0.011)\end{array}$ & $\begin{array}{l}-0.039^{* * *} \\
(0.010)\end{array}$ & $\begin{array}{l}-0.039^{* * *} \\
(0.010)\end{array}$ & $\begin{array}{l}0.419^{* * *} \\
(0.017)\end{array}$ & $\begin{array}{l}0.419^{* * *} \\
(0.017)\end{array}$ \\
\hline Secondary & $\begin{array}{l}-0.092^{* * *} \\
(0.014)\end{array}$ & $\begin{array}{l}-0.092^{* * *} \\
(0.015)\end{array}$ & $\begin{array}{l}-0.099^{* * *} \\
(0.011)\end{array}$ & $\begin{array}{l}-0.100^{* * *} \\
(0.011)\end{array}$ & $\begin{array}{l}0.271^{* * *} \\
(0.016)\end{array}$ & $\begin{array}{l}0.271^{* * *} \\
(0.017)\end{array}$ \\
\hline Middle & $\begin{array}{l}-0.081^{* * *} \\
(0.013)\end{array}$ & $\begin{array}{l}-0.081^{* * *} \\
(0.013)\end{array}$ & $\begin{array}{l}-0.093^{* * *} \\
(0.011)\end{array}$ & $\begin{array}{l}-0.094^{* * *} \\
(0.010)\end{array}$ & $\begin{array}{l}0.164^{* * *} \\
(0.012)\end{array}$ & $\begin{array}{l}0.164^{* * *} \\
(0.012)\end{array}$ \\
\hline Primary & $\begin{array}{l}-0.060^{* * *} \\
(0.006)\end{array}$ & $\begin{array}{l}-0.060^{* * *} \\
(0.006)\end{array}$ & $\begin{array}{l}-0.054^{* * *} \\
(0.006)\end{array}$ & $\begin{array}{l}-0.054^{* * *} \\
(0.006)\end{array}$ & $\begin{array}{l}0.158^{* * *} \\
(0.016)\end{array}$ & $\begin{array}{l}0.158^{* * *} \\
(0.016)\end{array}$ \\
\hline Age & $\begin{array}{l}0.013^{* * *} \\
(0.001)\end{array}$ & $\begin{array}{l}0.013^{* * *} \\
(0.001)\end{array}$ & $\begin{array}{l}0.017^{* * *} \\
(0.002)\end{array}$ & $\begin{array}{l}0.017^{* * *} \\
(0.002)\end{array}$ & $\begin{array}{l}0.010^{* * *} \\
(0.002)\end{array}$ & $\begin{array}{l}0.010^{* * *} \\
(0.002)\end{array}$ \\
\hline Age Square & $\begin{array}{l}-0.000^{* * *} \\
(0.000)\end{array}$ & $\begin{array}{l}-0.000^{* * *} \\
(0.000)\end{array}$ & $\begin{array}{l}-0.000^{* * *} \\
(0.000)\end{array}$ & $\begin{array}{l}-0.000^{* * *} \\
(0.000)\end{array}$ & $\begin{array}{l}-0.000^{* * *} \\
(0.000)\end{array}$ & $\begin{array}{l}-0.000^{* * *} \\
(0.000)\end{array}$ \\
\hline SC census population & $\begin{array}{l}-0.006^{* * *} \\
(0.002)\end{array}$ & $\begin{array}{l}0.002 \\
(0.003)\end{array}$ & $\begin{array}{l}-0.003 \\
(0.004)\end{array}$ & $\begin{array}{l}0.001 \\
(0.006)\end{array}$ & $\begin{array}{l}-0.012^{* * *} \\
(0.003)\end{array}$ & $\begin{array}{l}-0.013^{* *} \\
(0.005)\end{array}$ \\
\hline SC current population & $\begin{array}{l}-0.001 \\
(0.002)\end{array}$ & $\begin{array}{l}-0.001 \\
(0.002)\end{array}$ & $\begin{array}{l}-0.000 \\
(0.003)\end{array}$ & $\begin{array}{l}-0.001 \\
(0.003)\end{array}$ & $\begin{array}{l}0.008^{* * *} \\
(0.002)\end{array}$ & $\begin{array}{l}0.007^{* * *} \\
(0.002)\end{array}$ \\
\hline Lag(1) SDP & & $\begin{array}{l}-0.000 \\
(0.007)\end{array}$ & & $\begin{array}{l}-0.012 \\
(0.010)\end{array}$ & & $\begin{array}{l}0.004 \\
(0.008)\end{array}$ \\
\hline Population density & & $\begin{array}{l}0.000 \\
(0.000)\end{array}$ & & $\begin{array}{l}0.000^{* * * *} \\
(0.000)\end{array}$ & & $\begin{array}{l}-0.000^{* * *} \\
(0.000)\end{array}$ \\
\hline$R^{2}$ & 0.50 & 0.50 & 0.40 & 0.40 & 0.25 & 0.25 \\
\hline Number of observations & 613699 & 613699 & 613699 & 613699 & 297597 & 297597 \\
\hline
\end{tabular}

Notes: Clustered standard errors by state and time are in parentheses. All the specifications also include state fixed effects, time fixed effects, sector dummy, gender dummy, age, age square, married dummy, and religion dummies.

$\mathrm{SC} / \mathrm{ST}$ census population share is population shares measured by the most recent census.

$\mathrm{SC} / \mathrm{ST}$ current population share is the population share measured in current year.

* Significant at 10-percent level, ${ }^{* *}$ Significant at 5-percent level, and *** Significant at 1-percent level. 